\title{
Modulation of the Glutamate-Evoked Release of Arachidonic Acid from Mouse Cortical Neurons: Involvement of a pH-Sensitive Membrane Phospholipase $A_{2}$
}

\author{
Nephi Stella, ${ }^{1,2}$ Luc Pellerin, ${ }^{1}$ and Pierre J. Magistretti ${ }^{1}$ \\ 'Laboratoire de Recherches Neurologiques, Institut de Physiologie et Service de Neurologie du Chuv, Faculte de \\ Medecine, Université de Lausanne, 1005 Lausanne, Switzerland, and 'Laboratoire de Neuropharmacologie, \\ INSERM U114, Collège de France, 75231 Paris, Cedex 05, France
}

Excitatory synaptic transmission is associated with changes in both extracellular and intracellular $\mathrm{pH}$. Using mouse cortical neurons in primary cultures, we studied the sensitivity of glutamate-evoked release of ${ }^{3} \mathrm{H}$-arachidonic acid ( $\left.{ }^{3} \mathrm{H}-\mathrm{AA}\right)$ to changes in extracellular $\mathrm{pH}\left(\mathrm{pH}_{o}\right)$ and related intracellular $\mathrm{pH}\left(\mathrm{pH}_{i}\right)$. As $\mathrm{pH}_{o}$ was shifted from 7.2 to 7.8 , the glutamate-evoked release of ${ }^{3} \mathrm{H}$-AA was enhanced by threefold. The effect of alkaline $\mathrm{pH}_{0}$ on the glutamate response was rapid, becoming significant within $2 \mathrm{~min} .{ }^{3} \mathrm{H}-$ AA release, evoked by both NMDA and kainate, was also enhanced by $\mathrm{pH}_{o}$ alkalinization. NMDA- and kainate-induced increase in free intracellular $\mathrm{Ca}^{2+}$ was unaffected by changing $\mathrm{pH}_{o}$ from 7.2 to 7.8 , indicating that the receptorinduced $\mathrm{Ca}^{2+}$ influx is not responsible for the $\mathrm{pH}_{o}$ sensitivity of the glutamate-evoked release of ${ }^{3} \mathrm{H}-\mathrm{AA}$.

Alkalinization of $\mathrm{pH}_{i}$ obtained by incubating neurons in the presence of $\mathrm{HCO}_{3}{ }^{-}$or $\mathrm{NH}_{4}$ enhanced the glutamateevoked release of ${ }^{3} \mathrm{H}-\mathrm{AA}$, while $\mathrm{pH}_{i}$ acidification obtained by blockade of $\mathrm{Na}^{+} / \mathrm{H}^{+}$and $\mathrm{Cl}^{-} / \mathrm{HCO}_{3}^{-}$exchangers decreased the glutamate response. Membrane-bound phospholipase $A_{2}$ (mPLA $)$ activity was stimulated by $\mathrm{Ca}^{2+}$ in a $\mathrm{pH}$-dependent manner, increasing its activity as $\mathrm{pH}$ was shifted from 7.2 to 7.8 . This $\mathrm{pH}$ profile corresponds to the pH profile of the glutamate-, NMDA- and kainate-evoked release of ${ }^{3} \mathrm{H}-\mathrm{AA}$. Taken together, these results indicate that the glutamate-evoked release of ${ }^{3} \mathrm{H}-\mathrm{AA}$ may be mediated by the $\mathrm{pH}$-sensitive $\mathrm{mPLA}_{2}$. Since excitatory neurotransmission mediated by glutamate results in both $\mathrm{pH}_{0}$ and $\mathrm{pH}_{i}$ changes and since AA enhances glutamatergic neurotransmission at both pre- and postsynaptic levels, the data reported here reveals a possible molecular mechanism whereby glutamate can modulate its own signalling efficacy in a $\mathrm{pH}$-dependent manner by regulating the release of AA.

[Key words: $\mathrm{H}^{+}, \mathrm{NMDA}$, kainate, intracellular $\mathrm{Ca}^{2+}$, longterm potentiation, ischemia]

\footnotetext{
Received Aug. 1, 1994; revised Nov. 10, 1994; accepted Nov. 17, 1994.

We express our gratitude to Dr. Joël Prémont, Dr. Daniele Piomelli, Dr. JeanAntoine Girault, and Dr. Robert Williams for helpful suggestions and critica comments on the manuscript, and to Didier Gasser for excellent technical assistance. This work was supported by Fonds National de la Recherche Scientifique Grant 31-40565.94. to P.J.M

Correspondence should be addressed to Dr. N. Stella, Laboratoire de Recherches Neurologiques, Institut de Physiologie, 7 rue du Bugnon, 1005 Lausanne, Switzerland.

Copyright (C) 1995 Society for Neuroscience $0270-6474 / 95 / 153307-11 \$ 05.00 / 0$
}

Excitatory synaptic transmission is associated with both extracellular and intracellular changes in $\mathrm{pH}$ homeostasis. Extracellular $\mathrm{pH}\left(\mathrm{pH}_{o}\right)$ shifts to alkaline values (up to $0.4 \mathrm{pH}$ units) for several minutes after a brief electrically evoked depolarization (Kraig et al., 1983; Chesler and Chan, 1988). It has been proposed that $\mathrm{pH}_{o}$ changes are due to the exchange of $\mathrm{H}^{+}$equivalents principally between the interstitial space and surrounding glial cells (Chesler, 1990; Ransom, 1992). In line with this hypothesis, Bouvier et al. demonstrated that glutamate uptake into glial cells is associated with the countertransport of $\mathrm{OH}^{-}$to the extracellular medium (Bouvier et al., 1992). Thus, extracellular alkalinization could result from this neuronal-glial interaction due to glutamate reuptake into astrocytes. Glutamatergic neurotransmission can also induce intracellular $\mathrm{pH}\left(\mathrm{pH}_{i}\right)$ changes in neuronal cells, since rapid $\mathrm{pH}_{o}$ shifts induce $\mathrm{pH}_{i}$ shifts in the same direction within seconds (Ou-yang et al., 1993). In addition, activation of NMDA receptors modifies intracellular $\mathrm{H}^{+}$ homeostasis to alkaline values that last up to several hours (Hartley and Dubinsky, 1993). Thus, glutamatergic transmission is associated with complex and long-lasting changes in both $\mathrm{pH}_{0}$ and $\mathrm{pH}_{i}$. Such shifts in $\mathrm{pH}$ homeostasis could, in turn, modify the glutamate-mediated neurotransmission by affecting either glutamate transport (Tabb et al., 1992), glutamate receptors, or the signal transduction pathways associated with the activation of these receptors. For example, $\mathrm{pH}_{o}$-sensitive NMDA currents have been characterized (Tang et al., 1990; Traynelis and CullCandy, 1990).

Activation of glutamatergic receptors induces the formation of second messengers. In particular, glutamate evokes the release of arachidonic acid (AA) trom hippocampal slices (Pellerin and Wolfe, 1991), as well as from both neurons and astrocytes in primary culture (Dumuis et al., 1988, 1990; Lazarewicz et al., 1988; Sanfeliu et al., 1990; Tapia-Arancibia et al., 1990, 1992; Stella et al., 1994). This fatty acid is released from the $s n-2$ position of membrane phospholipids by the activation of various phospholipases, including phospholipases $\mathrm{A}_{2}$ (PLA $\mathrm{A}_{2}$ ) (Irvine, 1982; Dennis, 1994). Interestingly, brain synaptic vesicular $\mathrm{PLA}_{2}$ activity has been shown to be $\mathrm{pH}$ sensitive (Moskowitz et al., 1983). Taken together, this array of experimental evidence raises the question of whether changes in either $\mathrm{pH}_{o}$ or $\mathrm{pH}_{i}$ would affect the glutamate-evoked release of $\mathrm{AA}$. A pH sensitivity of the glutamate-evoked release of AA could have some relevance to the physiological regulation of glutamate neurotransmission, since it has been previously reported that $\mathrm{AA}$ itself modulates glutamate neurotransmission. Indeed, AA enhances 
NMDA currents (Miller et al., 1992), possibly by interacting with the ion channel protein itself (Petrou et al., 1993) and it may enhance the concentration of glutamate in the synaptic cleft by both increasing glutamate release from presynaptic terminals (Herrero et al., 1992) and by inhibiting glutamate reuptake (Yu et al., 1986; Barbour et al., 1989; Volterra et al., 1992).

Thus, the fine regulation of glutamate-evoked release of AA by either $\mathrm{pH}_{c}$ or $\mathrm{pH}_{i}$ would add yet another level of complexity to the feedback control of AA on glutamatergic neurotransmission. In this article, we used primary cultures of ccrcbral cortical neurons totally devoid of glial cells to characterize the glutamate-evoked release of $\mathrm{AA}$. We show that glutamate stimulates AA release in a $\mathrm{pH}$-dependent manner and describe the cascade of events that leads to this action. The data presented reveal a molecular mechanism whereby glutamate neurotransmission could regulate its own signalling efficacy.

\section{Materials and Methods}

\section{Materials}

Poly-L-ornithine (MW, 30,000-70,000), Dulbecco's modified Eagle's medium (DMEM; D-7777), bovine pancreas insulin, human apo-transferrin, putrescine, progesterone, 3-[4,5-dimethylthiazol-2-yl]-2,5-diphenyletrazolium bromide (MTT), fatty acid free bovine serum albumin (BSA), L-glutamate, L-aspartate, L-homocysteate, NMDA, kainate, D-serine, concanavalin A, 4,4'-diisothiocyanatostilbene-2,2'-disulfonic acid (DIDS), harmaline, and amiloride were obtained from Sigma, St.Quentin-Fallavier, France; $(R S)$ - $\alpha$-amino-3-hydroxy-5-methyl-4-isoxazolepropionic acid (AMPA), (1S,3R)-1-aminocyclopentane-1,3-dicarboxylic acid ( $t$-ACPD), L(+)-2-amino-3-phosphonopropionic acid (AP3), L-cysteate, 6-cyano-7-nitroquinoxaline-2,3-dione (CNQX), 6,7dinitroquinoxaline-2,3-dione (DNQX) from Tocris Neuramin, Bristol, England; 5R, 10S-(+)-5-methyl-10,11-dihydro-5-H-dibenzo [a,d] cyclohepten-5,10-imine hydrogen maleate (MK801) and D-2-amino-5phosphonopentanoic acid (AP5) from Research Biochemicals Incorporated, Natick, MA; adenosine deaminase (EC 3.5.44) from Boehringer, Mannheim, Germany; PTX from List, Campell, CA; myo- $\left[2-{ }^{3} \mathrm{H}\right]-$ inositol with PTG-27l [633 GBq (17.1 Ci)/mmol], ${ }^{3} \mathrm{H}$-arachidonic acid ( ${ }^{3} \mathrm{H}-$ $\mathrm{AA}, 8.25 \mathrm{TBq}(200 \mathrm{Ci}) / \mathrm{mmol})$, and ${ }^{14} \mathrm{C}$-arachidonic acid $\left[{ }^{14} \mathrm{C}-\mathrm{AA}, 2.15\right.$ $\mathrm{GBq}(58 \mathrm{mCi}) / \mathrm{mmol}$ ] from Amersham, Buckinghamshire, England; INDO-1 AM, 1,2-bis-(1-pyrenedecanoyl)-sn-glycero-3-phosphocholine (PPC); pyrenedecanoate from Molecular Probes, Eugene, OR.

\section{Methods}

Cell cullure. To obtain cultures devoid of glial cells, cortical neurons were prepared as described by DiPorzio and colleagues by taking advantage of the fact that non-neuronal cells do not proliferate in the absence of serum (DiPorzio et al., 1980). Accordingly, Swiss Albino timed-pregnant mice (Iffa Credo, Lyon, France) were killed by decapitation and 16-d-old embryos were removed. The embryos were decapitated and their heads were washed six times in a phosphate-buffered saline supplemented with $33 \mathrm{~mm}$ glucose (PBSglc). The cerebral cortex was dissected by removing the olfactory lobe, striatum, hippocampus, and meninges. Cells were dissociated mechanically through a flamenarrowed Pasteur pipette by two series of 15-20 gentle flushes in PBSglc (first in $5 \mathrm{ml}$ and then in $12 \mathrm{ml}$ ). Debris were removed by three centrifugations at $200 \times g$ for $5 \mathrm{~min}$. Cells $(800,000 \mathrm{cells} / \mathrm{ml})$ were plated on either 12-well Falcon culture dishes ( $1 \mathrm{ml} / \mathrm{well})$ or $90 \mathrm{~mm}$ dishes $(15 \mathrm{ml} / \mathrm{dish})$, previously coated for al leasl $2 \mathrm{hr}$ with $15 \mu \mathrm{g} / \mathrm{ml}$ polyornithine, rinsed once with water and then once with PBSglc. For intracellular $\mathrm{Ca}^{2+}\left(\left[\mathrm{Ca}^{2+}\right]_{i}\right)$ imaging, cells were plated on coverslips also coated with polyornithine, followed by $2 \mu \mathrm{g} / \mathrm{ml}$ laminin for at least 2 hr. In all cases, coating was carried out in serum-free medium. The medium was composed of DMEM supplemented with $2 \mathrm{~mm}$ glutamine, $7.5 \mathrm{~mm} \mathrm{NaHCO}, 5 \mathrm{~mm}$ HEPES buffer $(\mathrm{pH} 7.0), 100 \mu \mathrm{g} / \mathrm{ml}$ streptomycin, and $60 \mu \mathrm{g} / \mathrm{ml}$ penicillin. A mixture of hormones and salt containing $25 \mu \mathrm{g} / \mathrm{ml}$ insulin, $100 \mu \mathrm{g} / \mathrm{ml}$ transferrin, $60 \mu \mathrm{M}$ putrescine, 20 $\mathrm{nM}$ progesterone, and $30 \mathrm{~nm}$ sodium selenate was added to the culture medium. Cells were cultured at $37^{\circ} \mathrm{C}$ in a humidified atmosphere of $95 \%$ air and $5 \% \mathrm{CO}_{2}$.

Characterization of cell viability as a function of days in vitro. Neurons cultured in the total absence of serum have a limited viability with

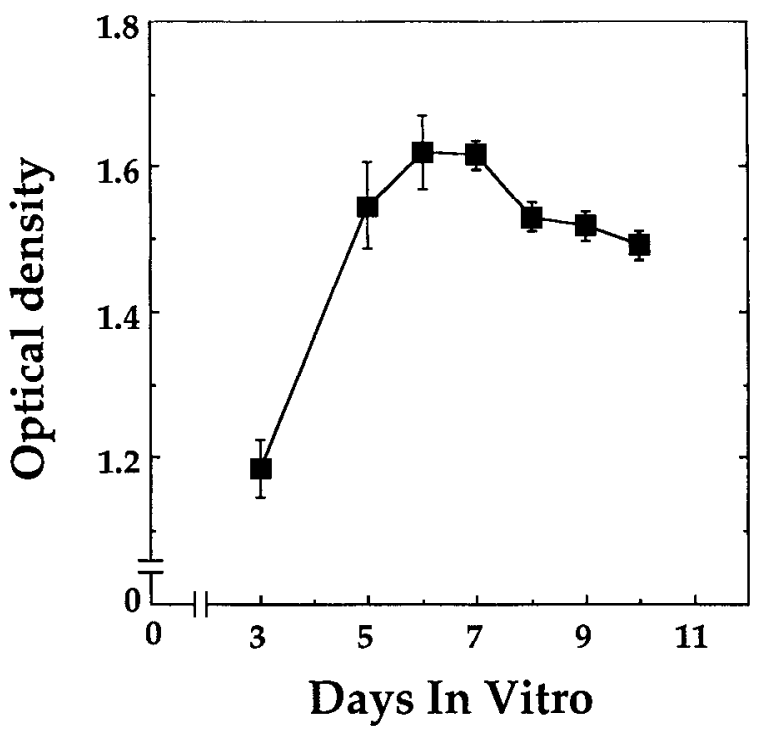

Figure 1. Viability of cortical neurons as a function of DIV. Cortical neurons at increasing DIV were incubated for $3 \mathrm{hr}$ in the presence of MTT, and formazan was measured as described in Materials and Methods. Results are the mean \pm SEM of three separate determinations from one experiment repeated twice with similar results.

incrcasing days in vitro (DIV) (DiPorzio et al., 1980). Thus, we characterized the viability of neurons in culture as a function of increasing DIV by measuring the cleavage of MTT into formazan as described by Denizot and Lang (1986). This reaction occurs only in living cells and is directly proportional to the activity of mitochondrial dehydrogenases (Slater et al., 1963). Briefly, cortical neurons cultured in 12-well culture dishes for increasing DIV were incubated for $3 \mathrm{hr}$ with MTT at a final concentration of $0.5 \mathrm{mg} / \mathrm{ml}$ added directly to the culture medium $(100$ $\mu \mathrm{l} / \mathrm{well}$ of a solution containing $5 \mathrm{mg} \mathrm{MTT} / \mathrm{ml}$ PBS). At the end of the incubation, the medium was removed and the precipitate was dissolved with $1 \mathrm{ml}$ dimethyl sulfoxide. Dishes were then shaken and optical density was measured at $560 \mathrm{~nm}$. Optical density of dissolved formazan reached a maximum between 6 and 7 DIV (Fig. 1). Therefore, in following experiments, cortical neurons were studied at $6 \pm 1$ DIV.

Immunocytochemical characterization. Cells grown for 6 DIV on glass coverslips (Deckgläser, Germany) in 12-well dishes were rinsed once with Dulbecco's phosphate-buffered salin (Dulbecco's PBS; pH 7.5; GIBCO, Eragny, France) at room temperature and fixed with $4 \%$ paraformaldehyde for 15 min. Each well was rinsed four times with Dulbecco's PBS and 10\% normal goat serum (Nordic Immunology) was then added for $30 \mathrm{~min}$ to the cells before applying the different monoclonal antibodies for $18 \mathrm{hr}$ at $4^{\circ} \mathrm{C}$. Antisera directed against neuronalspecific enolase (1:200; kindly provided by N. Lamandé, Collège de France, Paris, France; Secchi et al., 1980) and against neurofilament (1: 1000; SMI31; Sternberger, Baltimore, MD; Dahl, 1988) were used as neuronal markers. Antisera directed against glial fibrillary acidic protein (1:200, GFAP; ICN, Costa Mesa, CA), galactocerebroside (1/100; Boehringer), and MACl (1:10; Serotec, Oxford, England; Frei et al., 1987) were used as markers for astrocytes, oligodendrocytes, and microglia, respectively. For surface marker staining, cells were rinsed three times with Dulbecco's PBS containing $10 \%$ normal goat serum, whereas $0.1 \%$ Triton was also added for intracellular markers. Characterization was performed using indirect immunofluorescence staining by adding the secondary antibody for $1 \mathrm{hr}$ at room temperature. Cells were observed under a Nikon Optiphot microscope. Cells in the culture exclusively expressed neuronal markers, that is, neuronal-specific enolase and neurofilament $(94.3 \pm 1.2 \%$ and $98.8 \pm 0.8 \%$, respectively; both total and stained cells were counted: $n=10$; see Fig. $2 A, B$ ). No detectable staining was found for astrocytes, oligodendrocytes, or microglia, using GFAP, galactocerebroside, and MAC.1 antibodies, respectively (Fig. $2 C, D, E)$. Cortical neurons cultured up to 11 DIV were still GFAP negative (not shown).

Neuronal viability during acute glutamate application. It is well established that glutamate can be neurotoxic, depending on DIV or on glial density (Choi et al., 1987; Rosenberg et al., 1992). Therefore, we 
A

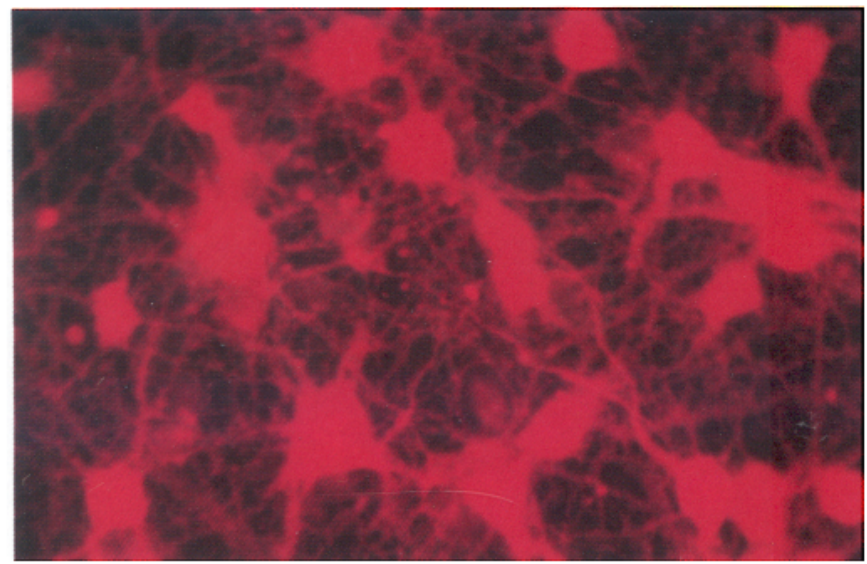

B

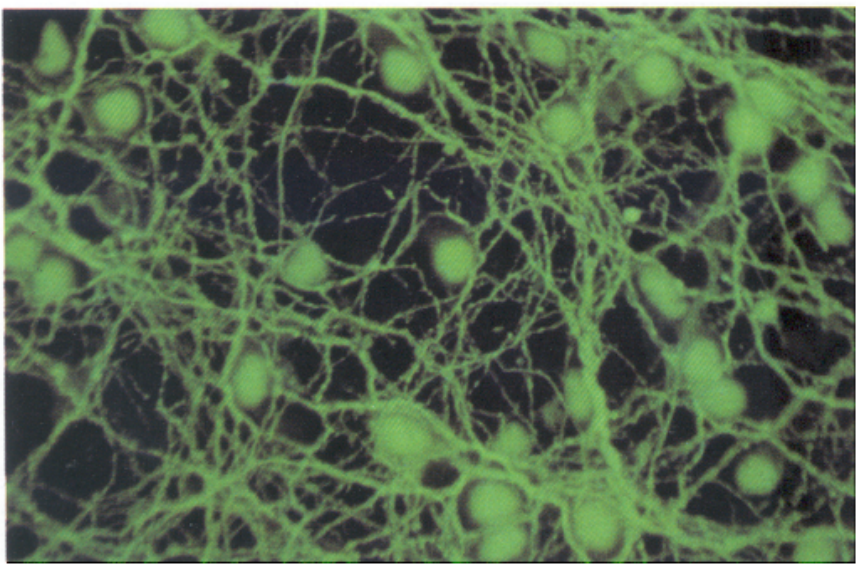

C

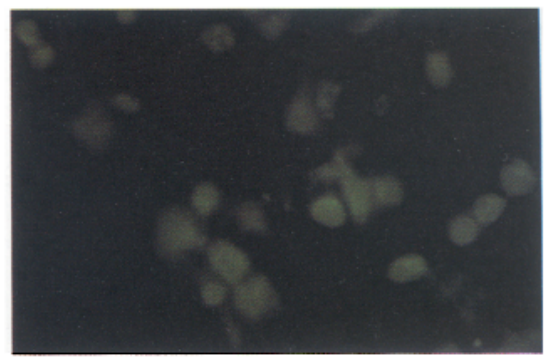

D

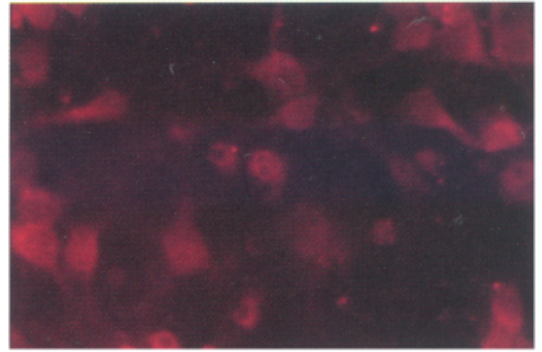

$\mathbf{E}$

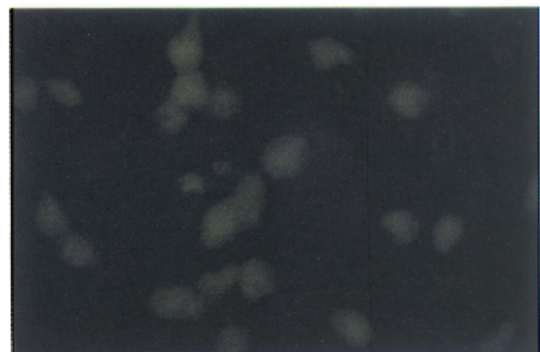

Figure 2. Immunocytostaining of cortical neurons. Six DIV neurons originating from 16-d-old embryonic mouse cerebral cortex were cultured in the total absence of serum and immunocytostained as described in Materials and Methods. Immunocytostaining for neuron specific enolase (a), neurofilaments $(b)$, GFAP $(c), \operatorname{Gal~C}(d)$, and Macl $(e)$ are shown.

investigated the potential neurotoxicity of glutamate by using Trypan blue as an index of plasma membrane permeation due to cell death. Application of $100 \mu \mathrm{M}$ glutamate to cortical neurons in primary culture for $15 \mathrm{~min}$ (i.e., the same conditions as those used for ${ }^{3} \mathrm{H}$-arachidonic acid ( $\left.{ }^{3} \mathrm{H}-\mathrm{AA}\right)$ release; see below), followed by addition of Trypan blue $(0.01 \% \mathrm{v} / \mathrm{v})$ revealed no difference in Trypan blue exclusion after this treatment when compared with untreated control neurons (not shown).

Measurement of ${ }^{3} \mathrm{H}$-arachidonic acid release. ${ }^{3} \mathrm{H}$-AA release was measured according to the method described by Lazarewicz et al. (1988), with minor modifications. Briefly, cortical neurons cultured in 12-well culture dishes were incubated for $18 \mathrm{hr}$ in the presence of ${ }^{3} \mathrm{H}$ AA $(1 \mu \mathrm{Ci} / 50 \mu \mathrm{l} \mathrm{PBSglc}+0.1 \% \mathrm{BSA} /$ well $)$ added to the culture medium. Under these conditions, cells incorporated $85-90 \%$ of the added radioactivity. When stated, cells were treated with PTX added to the culture medium during the labeling period. After washing three times at $37^{\circ} \mathrm{C}$ with a Locke-HEPES buffer (L-H buffer; in mM: $\mathrm{NaCl}, 145$; $\mathrm{KCl}, 5.5 ; \mathrm{CaCl}_{2}, 1.1 ; \mathrm{MgCl}_{2}, 1.1 ; \mathrm{NaHCO}_{3}, 3.6$; glucose, 5.5; HEPES, $20 ; \mathrm{pH}, 7.4 ; 1 \mathrm{ml} /$ well) containing $2 \mathrm{mg} / \mathrm{ml} \mathrm{BSA}$, cells were preincubated for $15 \mathrm{~min}$ in the same medium in the presence of adenosine deaminase $(1 \mathrm{IU} / \mathrm{ml})$. This latter procedure was used to degrade endogenous adenosine that has been previously shown to affect glutamatemediated signal transduction (El-Etr et al., 1992). Unless otherwise stated, inhibitors or antagonists were also added during this preincubation period. Cultures were then exposed for $15 \mathrm{~min}$ at $37^{\circ} \mathrm{C}$ to the agents

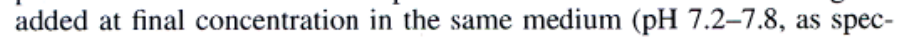
ified), but lacking $\mathrm{Mg}^{2+}$ (a condition necessary to yield full activity of NMDA receptors; Nowak et al., 1984; Mayer et al., 1984). At the end of the incubation, the medium was collected and centrifuged at $200 \times$ $g$ for $5 \mathrm{~min}$ to remove contamination by occasionally present detached cells. An aliquot of the supernatant was assayed for ${ }^{3} \mathrm{H}$ by liquid scintillation counting. Agonist-induced release into the extracellular medi- um corresponds to $1-3 \%$ of cellular ${ }^{3} \mathrm{H}$ content (see also Dumuis et al., 1988). The protein content of the cultures was determined by the method of Bradford (1976).

Thin-layer chromatography analysis of ${ }^{3} \mathrm{H}$-arachidonic acid release. In similar cortical neurons in primary cultures, it has been shown by reverse-phase HPLC that the radioactivity released into the incubation medium after glutamate stimulation is recovered in a single peak with a retention time identical to AA (Oomagari et al., 1991). Confirming these results, thin-layer chromatography (TLC) characterization of the ${ }^{3} \mathrm{H}$ labeled product(s) released from cortical neurons further support the conclusion that glutamate enhanced exclusively ${ }^{3} \mathrm{H}-\mathrm{AA}$ release. Briefly, a fixed amount of ${ }^{14} \mathrm{C}$-AA (internal standard) was added to $1.5 \mathrm{ml}$ of supernatant containing the released ${ }^{3} \mathrm{H}$-labeled product(s). Lipids were extracted by standard Folch extraction. Thus, $\mathrm{CHCl}_{3} / \mathrm{CH}_{3} \mathrm{OH}(2: 1 \mathrm{v} / \mathrm{v})$ was added to the supernatant to obtain a final proportion of $\mathrm{CHCl}_{3} /$ $\mathrm{CH}_{3} \mathrm{OH} / \mathrm{H}_{2} \mathrm{O}$ of 8:4:3. After complete phase separation, the lower phase was recovered, evaporated to dryness, and the final residue dissolved in $50 \mu \mathrm{l}$ of $\mathrm{CHCl}_{3} / \mathrm{CH}_{3} \mathrm{OH}(2: 1 \mathrm{v} / \mathrm{v})$. Samples, as well as nonradioactive standards were plated on dried TLC silica gel plates $(20 \times 20 \mathrm{~cm} ; 250$ $\mu \mathrm{m}$ thickness; Sigma), and separation was obtained by developing the plates in benzene/dioxan/acetic acid (60:40:2 by volume) as the mobile phase. This solvent system was shown to allow complete separation of AA from other classes of lipids such as phospholipids, mono- and diacylglycerols, as well as its own metabolites including prostaglandins and most lipoxygenase metabolites (Hurst et al., 1987). Nonradioactive standards, including AA, were visualized by spraying the TLC plate with phosphomolybdic acid (Sigma) and heating it by blowing hot air. Areas corresponding to each lipid class for each sample were scraped and ${ }^{3} \mathrm{H}$ and ${ }^{14} \mathrm{C}$ were assayed by liquid scintillation counting. Each value was corrected according to the recovery of internal standard, which was greater than $92 \%$ in all cases. 
Measurement of ${ }^{3} \mathrm{H}$-inositol phosphate formation. Cells were grown in the same conditions for 6 DIV in the presence of myo- $\left[2-{ }^{3} \mathrm{H}\right]$-inositol $(4 \mu \mathrm{Ci} / \mathrm{ml})$. The accumulation of ${ }^{3} \mathrm{H}$-inositol phosphates ( ${ }^{3} \mathrm{H}-\mathrm{IPs}$ ) was determined as described by (Berridge et al., 1982) with minor modifications. Briefly, cultures were washed three times with $\mathrm{L}-\mathrm{H}$ buffer ( 1 $\mathrm{ml} /$ well) at $37^{\circ} \mathrm{C}$, and subsequently preincubated for $15 \mathrm{~min}$ in $\mathrm{L}-\mathrm{H}$ buffer supplemented with lithium (10 mM) and adenosine deaminase (1 $\mathrm{IU} / \mathrm{ml})$. Cultures were then exposed for $15 \mathrm{~min}$ at $37^{\circ} \mathrm{C}$ to the agents added at a final concentration in a $\mathrm{Mg}^{2+}$-free $\mathrm{L}-\mathrm{H}$ buffer. The incubation was stopped by lysing the cells with successive addition of $0.1 \%$ Triton $\mathrm{X}-100$ in $0.1 \mathrm{M} \mathrm{NaOH}(400 \mu \mathrm{l})$ and $0.1 \%$ Triton $\mathrm{X}-100$ in $0.1 \mathrm{M} \mathrm{HCl}$ $(400 \mu \mathrm{l}) .{ }^{3} \mathrm{H}$ IPs contained in the lysate was isolated by addition of 1.5 $\mathrm{ml} \mathrm{CHCl}_{3} / \mathrm{CH}_{3} \mathrm{OH}(2: 1 \mathrm{v} / \mathrm{v})$, followed by $0.5 \mathrm{ml} \mathrm{CHCl}_{3}$ and by a centrifugation at $1000 \times g$ for $5 \mathrm{~min}$. An aliquot $(1 \mathrm{ml})$ of the upper aqueous phase was loaded onto Dowex $A G 1-\times 8$ columns (formate form, $200-400$ mesh, Bio-Rad) and myo- $\left[2-{ }^{3} \mathrm{H}\right]$-inositol was eluted with myo-inositol $(5 \mathrm{~mm}, 4 \mathrm{ml})$. Columns were then washed with formic acid $(0.1 \mathrm{M}, 10 \mathrm{ml})$ and total ${ }^{3} \mathrm{H}$-IPs, containing mainly ${ }^{3} \mathrm{H}$-monophosphate (more than $90 \%$ of total IPs; El-Etr et al., 1989) were eluted with $5 \mathrm{ml}$ ammonium formate $(1 \mathrm{M})$ /formic acid $(0.1 \mathrm{M})$. Radioactivity was measured by adding $\mathrm{H}_{2} \mathrm{O}(3 \mathrm{ml})$ and Aquasol $2(8 \mathrm{ml})$.

Intracellular $\left[\mathrm{Ca}^{2+}\right]$ determination. Determination of $\left[\mathrm{Ca}^{2+}\right]$, was carried out as previously described, with minor modifications (Marin et al., 1993). Briefly, cortical neurons grown on coverslips were studied with a dual emission microfluorimetry using the fluorescent dye INDO-1 AM. Cells were loaded for $60 \mathrm{~min}$ in the presence of $12 \mu \mathrm{M}$ of INDO- 1 AM in Locke-HEPES buffer. After loading, cells were exposed to various substances dissolved in Locke-HEPES buffer using a multichannel cell superfusion device allowing the complete change of the superfusion medium in less than $0.2 \mathrm{sec}$. All responses were measured in the absence of $\mathrm{Mg}^{2+}$. In addition, NMDA responses were examined in the presence of D-serine $(100 \mu \mathrm{M})$ to yield full NMDA receptor activation on perfused neurons (Johnson and Ascher, 1987). Cells were excited with a $75 \mathrm{~W}$ Xenon light filtered at $340 \mathrm{~nm}$ with a $10 \mathrm{~nm}$ wide interference filter. Excitation and emission spectra were separated by a $380 \mathrm{~nm}$ dichroic long-pass filter and the emission spectra were then divided in two halves by a dichroic long pass filter (Opticals were from Nikon). Two discriminant bands were selected from the two halves at $400-410 \mathrm{~nm}$ and $470-480 \mathrm{~nm}$, and both fluorescent images were digitized ( 8 video frames/digitized image). The camera dark noise was subtracted from the recorded crude image (camera and digitized system were from Hamamatsu Ltd., Japan).

Calculation of intracellular $\left[\mathrm{Ca}^{2+}\right]$ changes. The concentration of $\left[\mathrm{Ca}^{2+}\right]_{i}(\mathrm{nM})$ was calculated from the fluorescence ratio $(\mathrm{R})$ measured at $400-410 \mathrm{~nm}$ and $470-480 \mathrm{~nm}$, according to the equation described by Grynkiewicz et al. (1985): $\left[\mathrm{Ca}^{2+}\right]_{i}=K_{d} \times\left(F_{480 f} / F_{480+1}\right) \times\left(R-R_{\min }\right) /$ $\left(R_{\max }-R\right)$, where the $K_{d}$ of INDO-1 for ionized $\mathrm{Ca}^{2+}$ is $250 \mathrm{nM}, F_{480 f}$ is the fluorescence of free INDO- $1, F_{480 b}$ the fluorescence of INDO-1 bound to $\mathrm{Ca}^{2+}$, and $R$ is the ratio between fluorescences measured at 405 and $480 \mathrm{~nm} . R_{\max }$ and $R_{\min }$ was determined in the presence of ionomycin $(5 \mu \mathrm{M})$, with $1.1 \mathrm{ImM} \mathrm{CaCl}_{2}$ or 2 InM EGTA, respectively. $\left[\mathrm{Ca}^{2+}\right]_{i}$ was measured at $2.5 \mathrm{sec}$ intervals in the cell bodies of individual neurons. $\left[\mathrm{Ca}^{2+}\right]_{i}$ plateau values were expressed as the mean of the three highest and three lowest values observed during the application of agents to $n$ cells. Only data obtained during the first stimulation with the agonist were considered for calculations. Ninety-three and $92 \%$ of cells tested responded to NMDA $+D$-serine or kainate, respectively.

$P L A_{2}$ assay. PLA $A_{2}$ activity was determined according to the method described by Piomelli and Greengard (1991), with minor modifications. Briefly, cortical neurons prepared in $90 \mathrm{~mm}$ dishes were incubated under the same conditions as described for the ${ }^{3} \mathrm{H}-\mathrm{AA}$ release. The incubation was stopped by removing the buffer and by adding $1 \mathrm{ml}$ icccold hypotonic buffer (lysis buffer) containing $1 \mathrm{~mm}$ EDTA, $1 \mathrm{~mm}$ EGTA, $10 \mathrm{~mm}$ sodium pyrophosphate, $10 \mathrm{mM}$ HEPES, $5 \mu \mathrm{g} / \mathrm{ml}$ trypsin inhibitor (Sigma), and $0.1 \mu \mathrm{M}$ phenylmethylsulfonyl fluoride. Lysed cells were scraped and dishes were rinsed with $1 \mathrm{ml}$ of the same lysis buffer to recover remaining cellular elements. The lysate was centrifuged for $15 \mathrm{~min}$ at $40,000 \times g$ to separate cytoplasm from plasma membrane. The fluorogenic PLA $\mathrm{P}_{2}$ substrate PPC $(2 \mu \mathrm{M})$ was added to $1.5 \mathrm{ml}$ of $0.1 \mathrm{M}$ Tris-HC.I (at indicated $\mathrm{pH}$ ) in a stirred quartz cuvette maintained at $37^{\circ} \mathrm{C}$ within a F2000 Hitachi fluorimeter (excitation wavelength, $340 \mathrm{~nm}$; emission wavelength, $380 \mathrm{~nm}$ ). It should be noted that the PPC spectrum was insensitive to $\mathrm{pH}$ over the range used in the present study (not shown). After 3-4 min (fluorescence stabilization), a sample of either cytoplasm or membrane ( $25 \mu \mathrm{g}$ of protein) was trans-

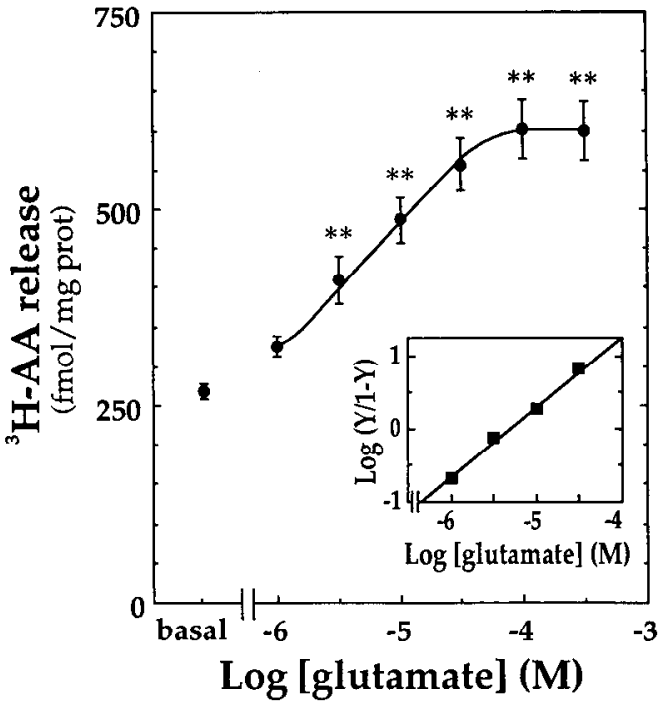

Figure 3. Glutamate evokes a concentration-dependent release of ${ }^{3} \mathrm{H}-$ arachidonic acid. Cortical neurons were incubated for $15 \mathrm{~min}$ with increasing concentrations of glutamate. ${ }^{3} \mathrm{H}$-AA release was determined as described in Materials and Methods. Results, expressed as fmol per mg of protein, are mean \pm SEM of 18 separate determinations for each concentration resulting from six different experiments. **, $p<0.01$ compared to basal 'H-AA release (ANOVA, followed by Dunnett's test). Inset, Hill plot of the concentration-dependent glutamate-evoked release of ${ }^{3} \mathrm{H}-\mathrm{AA}$.

ferred into the cuvette and the rate of increase in fluorescence due to the release of pyrenedecanoic acid was monitored every $5 \mathrm{sec}$ over a 2 min period. This measure represents the stable activity of the $\mathrm{Ca}^{2+}$ independent $\mathrm{PLA}_{2} \cdot \mathrm{Ca}^{2+}$-dependent $\mathrm{PLA}_{2}$ activity was determined by adding $\mathrm{Ca}^{2+}(2 \mathrm{~mm}$ final concentration) on a period of $2-5 \mathrm{~min}$, depending on the experiments. The changes in fluorescence duc to released pyrenedecanoate were calibrated against a known concentration of the unesterified fatty acid.

Statistical analysis. Results are expressed as mean \pm SEM of $n$ independent determinations. Data were statistically analyzed using INSTAT, GraphPad Software, San Diego, CA.

\section{Results}

\section{Characterization of the excilatory amino acid induced}

\section{${ }^{3} \mathrm{H}$-arachidonic acid release}

As previously demonstrated, both basal and $100 \mu \mathrm{M}$ glutamateevoked release of ${ }^{3} \mathrm{H}-\mathrm{AA}$ increased rapidly during the first 10 min of incubation to then reach a plateau (not shown, see Dumuis et al., 1988). Therefore, a 15 min incubation was used to investigate the effects of pharmacological agents on ${ }^{3} \mathrm{H}-\mathrm{AA}$ release. Glutamate evoked a concentration-dependent release of ${ }^{3} \mathrm{H}-\mathrm{AA}$ (Fig. 3) with an $\mathrm{EC}_{50}$ of $5 \mu \mathrm{M}$. Hill plot calculation by linear regression yields a slope of $0.989 \pm 0.04$ with a $r$ squared $=0.996$ (see inset, Fig. 3), indicating a noncooperative glutamate-evoked release of ${ }^{3} \mathrm{H}$-AA (Stryer, 1988). The efficacy of glutamate-evoked release of ${ }^{3} \mathrm{H}-\mathrm{AA}$ was maximal at a concentration of $100 \mu \mathrm{M}$ and reached $189 \pm 4 \%$ of basal (mean \pm SEM, $n=133$ ).

\section{Pharmacological profile of glutamate receptors mediating the release of ${ }^{3} \mathrm{H}$-arachidonic acid}

In agreement with previous studies, NMDA receptors are involved in the glutamate-evoked release of ${ }^{3} \mathrm{H}-\mathrm{AA}$ (Dumuis et al., 1988; Lazarewicz et al., 1988; Sanfeliu et al., 1990; TapiaArancibia et al., 1992). Indeed, $100 \mu \mathrm{M}$ NMDA partially reproduced the effect of glutamate (Fig. 4). Addition of $100 \mu \mathrm{M}$ D-ser- 


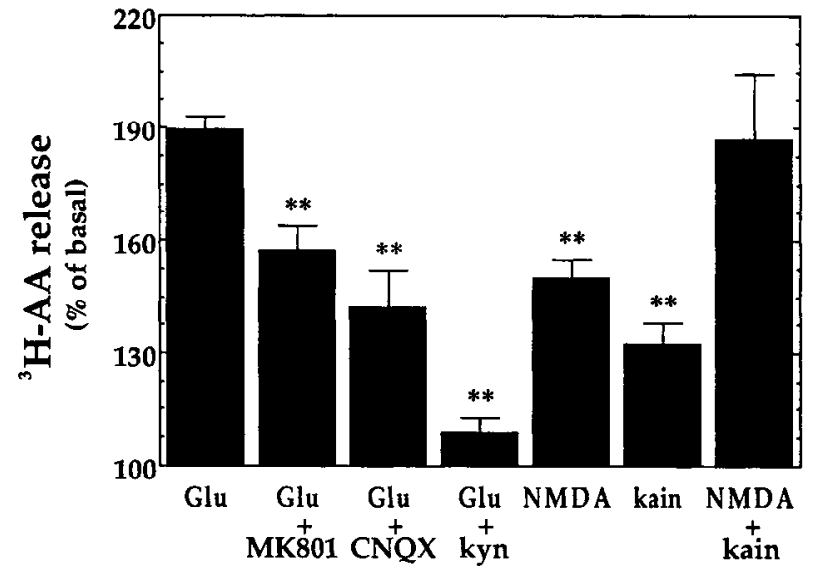

Figure 4. Effects of glutamatergic receptor agonists or antagonists on the release of ${ }^{3} \mathrm{H}$-arachidonic acid. Cortical neurons were incubated for 15 min with the different glutamate receptor agonists: glutamate (Glu, $100 \mu \mathrm{M} ; n=133)$, NMDA $(100 \mu \mathrm{M} ; n=48)$, and kainate (kain, 100 $\mu \mathrm{M} ; n=27) .{ }^{3} \mathrm{H}$-AA release was determined as described in Materials and Methods, and results are expressed as percent of basal. Data are the mean \pm SEM of $n$ separate determinations and statistical analysis indicated: $* *, p<0.01$ significantly different from the glutamateevoked ${ }^{3} \mathrm{H}$-AA release (ANOVA followed by Dunnett's test). Antagonists of ionotropic glutamatergic receptors: $M K 801(1 \mu \mathrm{M} ; n=18)$, $C N Q X(10 \mu \mathrm{M} ; n=15)$ and kynurenate $(K y n, 1 \mathrm{mM} ; n=12)$ were added both $15 \mathrm{~min}$ prior and during the $15 \mathrm{~min}$ incubation with 100 $\mu \mathrm{M}$ glutamate. Ionotropic antagonists alone did not significantly influence the basal release of ${ }^{3} \mathrm{H}-\mathrm{AA}: \mathrm{MK} 801,107 \pm 5 \%$, CNQX, $110 \pm$ $10 \%$, and kyn, $95 \pm 7 \%$ of basal.

ine, an agonist of the glycine binding sites on NMD $\Lambda$ receptors and a positive modulator of these receptors (Johnson and Ascher, 1987) did not significantly increase the NMDA-evoked release of ${ }^{3} \mathrm{H}-\mathrm{AA}(139 \pm 4 \%$ and $138 \pm 5 \%$ of basal, without or with D-serine, respectively; both $n=6$ ). Furthermore, the response evoked by $100 \mu \mathrm{M}$ glutamate was partially inhibited by both competitive and noncompetitive antagonists of the NMDA receptors, that is, AP5 at $100 \mu \mathrm{M}$ and MK801 at $1 \mu \mathrm{M}(57$ 1. 7\% and $63 \pm 8 \%$ of the $100 \mu \mathrm{M}$ glutamate response, respectively; Fig. 4). Other endogenous excitatory amino acids known to preferentially activate NMDA receptors were tested (Watkins et al., 1990). Thus, aspartate $(100 \mu \mathrm{M})$, homocysteate ( $1 \mathrm{mM})$, and cysteate $(1 \mathrm{~mm})$ also evoked ${ }^{3} \mathrm{H}$-AA release $(151 \pm 14 \% ; 162 \pm$ $6 \%$, and $156 \pm 10 \%$ of basal, respectively; for each agonist $n$ $=9$ ). The concentrations used were all maximally effective (not shown).

The involvement of AMPA/kainate receptors has also been proposed for the glutamate-evoked release of ${ }^{3} \mathrm{H}-\mathrm{AA}$ (Patel et al., 1990). Here, neither the selective agonist of AMPA receptors, that is, AMPA at $100 \mu \mathrm{M}$ nor the selective agonist of kainate receptors, that is, domoic acid at $1 \mu \mathrm{M}$ (Watkins et al., 1990) significantly increased the release of ${ }^{3} \mathrm{H}-\mathrm{AA}[106 \pm 4 \%(n=$ 12) and $105 \pm 4 \%(n=6)$ of basal, respectively]. However, either kainate $(100 \mu \mathrm{M})$ or AMPA $(100 \mu \mathrm{M})$ in the presence of $100 \mu \mathrm{g} / \mathrm{ml}$ concanavalin $\mathrm{A}$, an agent previously shown to prevent AMPA receptor desensitization (Huettner, 1990), were active (132 $\pm 6 \%$ and $147 \pm 4 \%$ of basal, respectively; Fig. 4). This result suggests that the action of kainate may be mediated through nondesensitizing AMPA receptors. Accordingly, the stimulatory effect of glutamate was partially antagonized by either $10 \mu \mathrm{M}$ CNQX or $10 \mu \mathrm{M}$ DNQX (46 $\pm 11 \%$ and $35 \pm$ $16 \%$ of the $100 \mu \mathrm{M}$ glutamate response, respectively; Fig. 4).
Additivity of NMDA and AMPA/kainate receptor activation on the release of ${ }^{3} \mathrm{H}$-arachidonic acid

An additive response between NMDA and AMPA/kainate receptor activation on the induced release of ${ }^{3} \mathrm{H}-\mathrm{AA}$ has already been described on neuronal cultures originating from mouse striatal cells (Dumuis et al., 1990). At a maximally effective concentration, $100 \mu \mathrm{M}$ NMDA in the presence of $100 \mu \mathrm{M}$ kainate elicited an additive release of ${ }^{3} \mathrm{H}-\mathrm{AA}$ (Fig. 4). Confirming the involvement of both NMDA and AMPA/kainate receptors in the glutamate response, a broad antagonist of ionotropic receptors, that is, kynurenate at $1 \mathrm{~mm}$ strongly antagonized the glutamateevoked release of ${ }^{3} \mathrm{H}-\mathrm{AA}$ (Fig. 4).

\section{Noninvolvement of metabotropic receptors in the} glutamate-evoked release of ${ }^{3} \mathrm{H}$-arachidonic acid

Metabotropic glutamate receptors are present in 6 DIV cortical neurons, since $100 \mu \mathrm{M}$ glutamate and $1 \mathrm{~mm} t$-ACPD stimulated the formation of ${ }^{3} \mathrm{H}-\mathrm{IPs}(200 \pm 10 \%$ and $149 \pm 10 \%$ of basal, $n=9$ ). However, metabotropic glutamate receptors are not involved in the glutamate-evoked release of ${ }^{3} \mathrm{H}-\mathrm{AA}$. Indeed, $t$-ACPD at $1 \mathrm{~mm}$ did not significantly increase the basal release of ${ }^{3} \mathrm{H}-\mathrm{AA}(110 \pm 4 \%$ of basal, $n=12)$ and a competitive antagonist, that is, $1 \mathrm{mM} \mathrm{AP3}$, failed to significantly decrease the glutamate-evoked release of ${ }^{3} \mathrm{H}-\mathrm{AA}(92 \pm 7 \%$ of the 100 $\mu \mathrm{M}$ glutamate response, $n=12$ ). The combination of $100 \mu \mathrm{M}$ AMPA and $1 \mathrm{~mm} t$-ACPD did not significantly increase the basal release of ${ }^{3} \mathrm{H}-\mathrm{AA}(112 \pm 8 \%$ of basal, $n=9$ ). Metabotropic glutamate receptors are linked to G-proteins (Nakanishi, 1992; Pin et al., 1994). When cortical neurons were incubated for 24 hr with $1 \mu \mathrm{g} / \mathrm{ml}$ pertussis toxin, both basal and glutamate-evoked release of ${ }^{3} \mathrm{H}$-AA were unchanged, confirming that neither $\mathrm{Gi}$ nor Go proteins were involved in this response (not shown).

\section{Extracellular $p H$ modulates the glutamate-evoked release of ${ }^{3} \mathrm{H}$-arachidonic acid}

Because the activity of purified $\mathrm{PLA}_{2}$ is $\mathrm{pH}$ sensitive (Moskowitz et al., 1983), we investigated the effect of extracellular $\mathrm{pH}$ $\left(\mathrm{pH}_{o}\right)$ changes on the glutamate-evoked release of ${ }^{3} \mathrm{H}-\mathrm{AA}$ from cortical neurons in primary cultures. At this point, it is important to note that changes in $\mathrm{pH}_{o}$ are reflected within seconds by intracellular $\mathrm{pH}\left(\mathrm{pH}_{i}\right)$ shifts in the same direction (Ou-yang et al., 1993).

\section{The glutamate-evoked release of ${ }^{3} \mathrm{H}$-arachidonic acid is $p H_{0}$ sensitive}

In these experiments, the incubation medium was buffered every 0.2 units between $\mathrm{pH}_{o} 7.2$ and 7.8 (see Material and Methods). As shown in Figure 5, the release of ${ }^{3} \mathrm{H}$-AA evoked by glutamate $(100 \mu \mathrm{M})$ was enhanced as the extracellular medium was alkalinized. In particular, the glutamate response measured at $\mathrm{pH}_{0}$ 7.8 was 2.8 -fold greater than that measured at 7.2. Using TLC, we verified that the glutamate-evoked release of ${ }^{3} \mathrm{H}$-labeled product(s) observed at either 7.2 or 7.8 werc cxclusively accounted for by an increase in ${ }^{3} \mathrm{H}-\mathrm{AA}$ release. In fact, the glutamate-evoked release of ${ }^{3} \mathrm{H}$-AA seen by TLC was also 2.8 -fold greater at $\mathrm{pH}_{o} 7.8$ compared to 7.2. Thus, in two separate experiments, ${ }^{3} \mathrm{H}-\mathrm{AA}$-evoked release at $\mathrm{pH}_{\circ} 7.2$ was 187 and 167 $\mathrm{fmol} / \mathrm{mg}$ protein over basal, while at $\mathrm{pH}_{o} 7.8$ it was 456 and 520 $\mathrm{fmol} / \mathrm{mg}$ protein over basal, with a ${ }^{3} \mathrm{H}$-AA basal release of 64 and $75 \mathrm{fmol} / \mathrm{mg}$ protein, respectively. Changes in $\mathrm{pH}_{o}$ rapidly modified the glutamate-evoked release of ${ }^{3} \mathrm{H}$-AA. Indeed, a sig- 


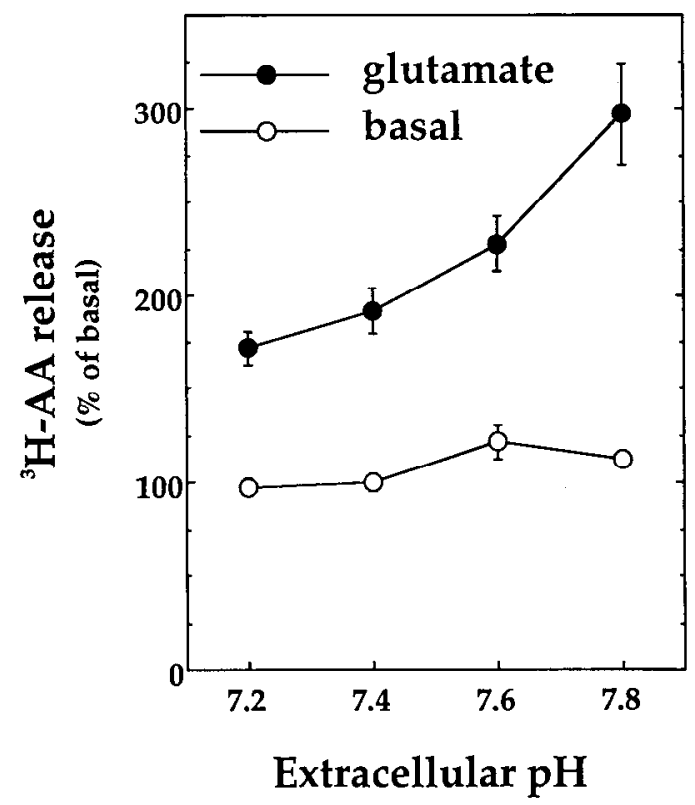

Figure 5. $\mathrm{pH}$ dependence of the glutamate-evoked release of ${ }^{3} \mathrm{H}$-arachidonic acid. Cortical neurons were incubated for $15 \mathrm{~min}$ with 100 $\mu \mathrm{M}$ glutamate in a buffer at indicated $\mathrm{pH}$. ${ }^{3} \mathrm{H}-\mathrm{AA}$ release was determined as described in Materials and Methods. Results are the mean \pm SEM of $n=12$ separate determinations from four independent experiments.

nificant difference was observed 2 min after glutamate application at $\mathrm{pH}_{o} 7.2$ or 7.8 (Fig. 6).

NMDA- and kainate-evoked release of ${ }^{3} \mathrm{H}$-arachidonic acid are $\mathrm{pH}_{\mathrm{o}}$ sensitive, while the increase in free intracellular $\mathrm{Ca}^{2+}$ is not

NMDA currents have been shown to be $\mathrm{pH}_{\circ}$ sensitive, whereas AMPA/kainate currents are not (Tang et al., 1990; Traynelis and Cull-Candy, 1990). Here, both the NMDA (100 $\mu \mathrm{M})$ and the kainate $(100 \mu \mathrm{M})$-evoked release of ${ }^{3} \mathrm{H}$-AA were increased by $\mathrm{pH}_{0}$ alkalinization (Fig. 7). This suggest that the $\mathrm{pH}$-sensitive mechanism resulting in enhanced release of $\mathrm{AA}$ is independent of receptor activated currents. Interestingly, the NMDA- and kainate-evoked release of ${ }^{3} \mathrm{H}-\mathrm{AA}$ measured at $\mathrm{pH}_{o} 7.8$ were both $\sim$ threefold greater than those observed at $\mathrm{pH}_{o}$ 7.2.

The activity of $\mathrm{PLA}_{2}$ and the glutamate-evoked release of ${ }^{3} \mathrm{H}$ AA are dependent on intracellular $\mathrm{Ca}^{2+}$ concentration $\left(\left[\mathrm{Ca}^{2+}\right]_{i}\right.$ ) (Dumuis et al., 1988, 1993; Lazarewicz et al., 1990; Clark et al., 1991). Since activation of both NMDA and kainate receptors are known to induce $\left[\mathrm{Ca}^{2+}\right]_{i}$ increases, a sensitivity of these $\left[\mathrm{Ca}^{2+}\right]_{i}$ increases to $\mathrm{pH}$ could account for the $\mathrm{pH}$ sensitivity of ${ }^{3} \mathrm{H}-\mathrm{AA}-$-evoked release. Hence, we measured these receptor-mediated $\left[\mathrm{Ca}^{2+}\right]_{i}$ increases with the INDO-1 fluorescent dye at $\mathrm{pH}_{o}$ 7.2 and 7.8. The general pattern of NMDA- and kainate-induced $\left[\mathrm{Ca}^{2+}\right]_{i}$ increases were similar when studied at both $\mathrm{pH}_{o}$. In particular, application of either agonist at $\mathrm{pH}_{o} 7.2$ or 7.8 revealed that initial $\left[\mathrm{Ca}^{2+}\right]_{i}$ increases measured between basal and the beginning of $\left[\mathrm{Ca}^{3+}\right]$, plateau levels, that is, $10 \mathrm{sec}$, were unchanged. $\left[\mathrm{Ca}^{2+}\right]_{i}$ increase evoked by NMDA studied in 70 cortical neurons was $71 \pm 8$ and $86 \pm 7 \mathrm{~nm} / \mathrm{sec}$, at $\mathrm{pH}_{o} 7.2$ and 7.8 , respectively. Furthermore, kainate-induced $\left[\mathrm{Ca}^{2+}\right]_{i}$ increases in 67 cortical neurons was $28 \pm 3$ and $31 \pm 4 \mathrm{~nm} / \mathrm{sec}$, at $\mathrm{pH}_{0}$ 7.2 and 7.8 ; respectively. No significant difference was found when NMDA- and kainate-induced $\left[\mathrm{Ca}^{2+}\right]_{i}$ increases were com-

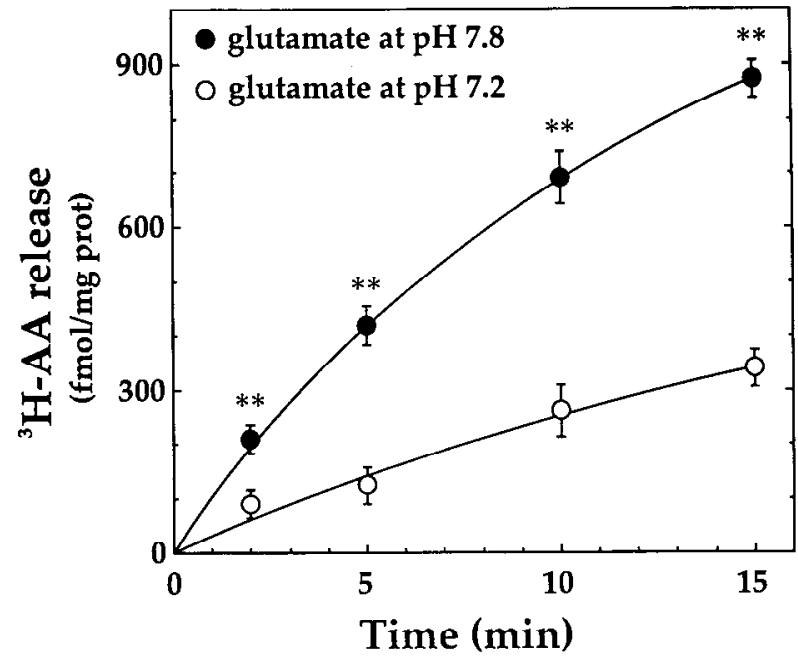

Figure 6. Kinetic of the $\mathrm{pH}_{4}$-dependent glutamate-evoked release of ${ }^{3} \mathrm{H}$-arachidonic acid. Cortical neurons were incubated for increasing periods with $100 \mu \mathrm{M}$ glutamate in buffer at either $\mathrm{pH}_{o} 7.2$ or 7.8 and ${ }^{3} \mathrm{H}-$ AA release was determined as described in Materials and Methods. Results are expressed as absolute increases in fmol per mg of protein above corresponding basal ${ }^{3} \mathrm{H}$-AA release. Basal ${ }^{3} \mathrm{H}$-AA release at each time point was $232 \pm 24,267 \pm 15,353 \pm 22$, and $492 \pm 11 \mathrm{fmol} /$ $\mathrm{mg}$ protein at, respectively, $2,5,10$, and $15 \mathrm{~min}$. Results are mean \pm SEM of $n=12$ separate determinations from four independent experiments. Statistical analysis: ${ }^{* *}, p<0.01$ significantly different from corresponding glutamate-evoked ${ }^{3} \mathrm{H}-\mathrm{AA}$ release at $\mathrm{pH}_{*} 7.2$ (unpaired Student $t$ test).

pared at each $\mathrm{pH}_{0}$ (two-tailed unpaired Student $t$ test; $p>0.05$ ). Table 1 shows that a similar $\left[\mathrm{Ca}^{2+}\right]_{i}$ plateau value was reached at either $\mathrm{pH}_{o} 7.2$ or 7.8 after NMDA or kainate application.

Intracellular $\mathrm{pH}$ modulates the glutamate-evoked release of ${ }^{3} \mathrm{H}$-arachidonic acid

It has been shown that $\mathrm{pH}_{i}$ can be changed by directly affecting $\mathrm{H}^{+}$equivalents exchange (Ou-yang et al., 1993). In hippocampal neurons, it has been shown that the resting $\mathrm{pH}_{i}$ is $0.2-0.3$ higher when cells are maintained in a $\mathrm{HCO}_{3}$-buffered solution com-

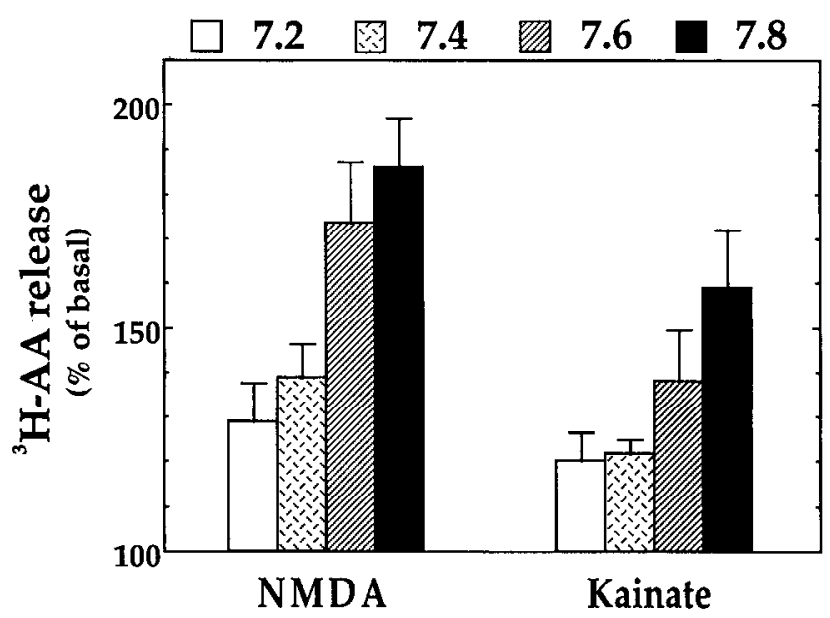

Figure 7. $\mathrm{pH}_{s}$ Dependence of both NMDA- and the kainate-evoked release of ${ }^{3} \mathrm{H}$-arachidonic acid. Cortical neurons were incubated for 15 min with NMDA $(100 \mu \mathrm{M})$ or kainate $(100 \mu \mathrm{M})$ in buffer at indicated $\mathrm{pH}_{o} .{ }^{3} \mathrm{H}-\mathrm{AA}$ release was determined as described in Materials and Methods. Results are mean \pm SEM of $n=12$ separate determinations from four independent experiments. 
Table 1. Insensitivity to pHo of NMDA- and kainate-induced $\left[\mathrm{Ca}^{2+}\right]_{i}$ elevations

\begin{tabular}{llll}
\multicolumn{5}{c}{} & {$\left[\mathrm{Ca}^{2+}\right]_{i}(\mathrm{nM})$} & & \\
\cline { 2 - 4 } $\mathrm{pH}$ & Basal & NMDA & Kainate \\
\hline 7.2 & $57 \pm 3$ & $673 \pm 68$ & $419 \pm 53$ \\
7.8 & $43 \pm 2$ & $745 \pm 54$ & $397 \pm 39$
\end{tabular}

Elevation in $\left[\mathrm{Ca}^{2}\right]_{i}$ was measured in INDO-1-loaded cortical neurons exposed for a period of $2 \mathrm{~min}$ either to $100 \mu \mathrm{M}$ NMDA $+100 \mu \mathrm{M}$ D-serine or to 100 $\mu \mathrm{M}$ kainate. Incubation medium lacking $\mathrm{Mg}^{2+}$ was buffered at the indicated

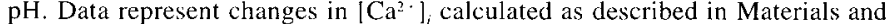
Methods, corresponding to $n$ individual neurons subjected to identical treatments and chosen at random from three independent coverslips. $n=66$ and 71 for NMDA + D-serine at $\mathrm{pH} 7.2$ and 7.8 , respectively; $n=58$ and 75 for kainate at $\mathrm{pH} 7.2$ and 7.8 , respectively. No significant difference was found when NMDA and kainate responses were compared at each pII (two-tailed unpaired Student $t$ test, $p>0.05$ ).

pared to a nominally $\mathrm{HCO}_{3}$-free solution (Raley-Susman et al., 1991; Schwiening and Boron, 1994). In line with these observations, glutamate $(100 \mu \mathrm{M})$ evoked a significantly smaller release of ${ }^{3} \mathrm{H}-\mathrm{AA}$ when $\mathrm{NaHCO}_{3}$ was removed from the buffered solution (see Materials and Methods) (190 $\pm 8 \%$ and $171 \pm$ $6 \%$ of basal, with and without $3.6 \mathrm{mM} \mathrm{NaHCO}_{3}$, respectively; $n$ $=6 ; p<0.05$ with two-tailed unpaired Student $t$ test). To further confirm this observation, we incubated cortical neurons in a buffer containing $30 \mathrm{~mm} \mathrm{NH} \mathrm{NH}_{4} \mathrm{Cl}$, a treatment that is known to alkalinize $\mathrm{pH}_{i}$ (Raley-Susman et al., 1991; Schwiening and Boron, 1994). Following this treatment, the glutamate response was also enhanced (Table 2).

Two major types of specific antiport are involved in the proton homeostasis of cells, the $\mathrm{Na}^{+} / \mathrm{H}^{+}$and the $\mathrm{Cl}^{-} / \mathrm{HCO}_{3}^{-}$carrier. Thus, inhibition of both activities results in intracellular acidosis (Hartley and Dubinsky, 1993; Ou-yang et al., 1993). Incubation of cells with glutamate $(100 \mu \mathrm{M})$ in the presence of $\mathrm{Na}^{+} / \mathrm{H}^{+}$ exchange inhibitors, that is, amiloride at $1 \mathrm{~mm}$ or harmaline at $100 \mu \mathrm{M}$, significantly inhibited the glutamate-evoked ${ }^{3} \mathrm{H}-\mathrm{AA}$ release (Table 2). Likewise, inhibition of $\mathrm{Cl}^{-} / \mathrm{HCO}_{3}^{-}$by $100 \mu \mathrm{M}$ DIDS also significantly decreased the glutamate-evoked ${ }^{3} \mathrm{H}-\mathrm{AA}$ release (Table 2 ).

\section{pH Sensitivity of membrane-bound $\mathrm{Ca}^{2+}$-dependent $\mathrm{PLA}_{2}$ activities}

$\mathrm{PLA}_{2}$ activities are present both in the cytoplasmic compartment $\left(\mathrm{cPLA}_{2}\right)$ and bound to the plasma membrane $\left(\mathrm{mPLA}_{2}\right)$. In cortical synaptosomes, $\mathrm{Ca}^{2+}$-independent and $\mathrm{Ca}^{2+}$-dependent $\mathrm{PLA}_{2}$ activity for each compartment has been described (Piomelli and Greengard, 1991). We therefore studied the effect of $\mathrm{pH}$ on these four PLA $\mathrm{PL}_{2}$ activities.

$p H$ sensitivity of membrane-bound PLA $A_{2}$ activity. When membranes were incubated at $\mathrm{pH} 7.2$ in the presence of the fluorogenic $\mathrm{PLA}_{2}$ substrate PPC, a basal $\mathrm{Ca}^{2+}$-independent $\mathrm{mPLA}_{2}$ activity was measured $(4.7 \mathrm{nmol} / \mathrm{mg}$ of protein/sec). Increasing the $\mathrm{pH}$ of incubation medium from 7.2 to 7.8 did not change this basal $\mathrm{Ca}^{2+}$-independent mPLA $_{2}$ activity, which was measured over a 2 min period (see Materials and Methods and Fig. $8 A$, before $\mathrm{Ca}^{2+}$ addition).

Addition of $2 \mathrm{mM} \mathrm{Ca}^{2+}$ revealed a $\mathrm{Ca}^{2+}$-dependent $\mathrm{mPLA}_{2}$ activity. $\mathrm{Ca}^{2+}$ induced a transient acceleration of the $\mathrm{mPLA}_{2}$ activity that reached a maximum at $20 \mathrm{sec}$, returning to the initial basal activity after another $20 \mathrm{sec}$ (Fig. 8A). $\mathrm{Ca}^{2+}$ addition not only induced an initial acceleration of the $\mathrm{Ca}^{2+}$-dependent $\mathrm{mPLA}_{2}$, but it was also followed by a transient inhibition of the
Table 2. Effect of pH-regulating carrier inhibitors on the glutamate-evoked release of ${ }^{3} \mathrm{H}$-arachidonic acid

\begin{tabular}{lccc} 
& \multicolumn{3}{c}{$\begin{array}{l}\text { 3 } \mathrm{H}-\mathrm{A} \text { A release } \\
\text { (\% of basal release) }\end{array}$} \\
\cline { 2 - 4 } Agents added & $\mathrm{mm}$ & \multicolumn{1}{c}{ Basal } & + Glutamate \\
\hline None & & $100 \pm 2$ & $188 \pm 8$ \\
$\mathrm{NH}_{4} \mathrm{Cl}$ & 30 & $132 \pm 7$ & $231 \pm 7^{* *}$ \\
Harmaline & 0.1 & $86 \pm 13$ & $101 \pm 9^{* *}$ \\
Amiloride & 1 & $100 \pm 5$ & $116 \pm 9^{* *}$ \\
DIDS & 0.1 & $106 \pm 5$ & $144 \pm 10^{* *}$ \\
\hline
\end{tabular}

Cortical neurons were incubated for $15 \mathrm{~min}$ with different $\mathrm{pH}$-regulating carriers inhibitors. Agents were added at the same time as glutamate. ${ }^{3} \mathrm{H}-\mathrm{AA}$ release was determined as described in Materials and Methods. Results are expressed as percentage of basal H-AA release. Results for each treatment are the mean \pm SEM of $n=12$ separate determinations from four independent experiments.

$* * p<0.01$ compared to glutamate-evoked ${ }^{3} \mathrm{H}-\mathrm{AA}$ release (ANOVA followed by Dunnett's test).

mPL $A_{2}$ activity (Fig. $8 A$ ). This inhibitory process occurred in two phases: first a strong inhibition occurred for approximately $60 \mathrm{sec}$, followed by a weaker inhibition that was maintained for at least $200 \mathrm{sec}$. Together, the two phases of the inhibitory process were always lower than the basal mPLA $A_{2}$ activity (Fig. $8 A$ ).

$\mathrm{Ca}^{2+}$-dependent mPLA $\mathrm{A}_{2}$ activity measured at $20 \mathrm{sec}$ after addition of $\mathrm{Ca}^{2+}$ was increased as the incubation $\mathrm{pH}$ was changed every $0.2 \mathrm{pH}$ units from 7.2 to 7.8 (Fig. $8 B$ ). Interestingly, the $\mathrm{Ca}^{3+}$-dependent $\mathrm{mPLA}_{2}$ activity measured at $20 \mathrm{sec}$ in the incubation medium buffered at 7.8 was 3.4 -fold greater than the response measured at 7.2 . In addition, the inhibitory phase that follows $\mathrm{Ca}^{2+}$-evoked $\mathrm{mPLA}_{2}$ activation was less pronounced at 7.8 than at 7.2 (Fig. $8 A$ ).

$\mathrm{pH}$ insensitivity of cytosolic PLA $\mathrm{A}_{2}$ activity. When cytoplasmic homogenates were incubated at $\mathrm{pH} 7.2$ in the presence of fluo-
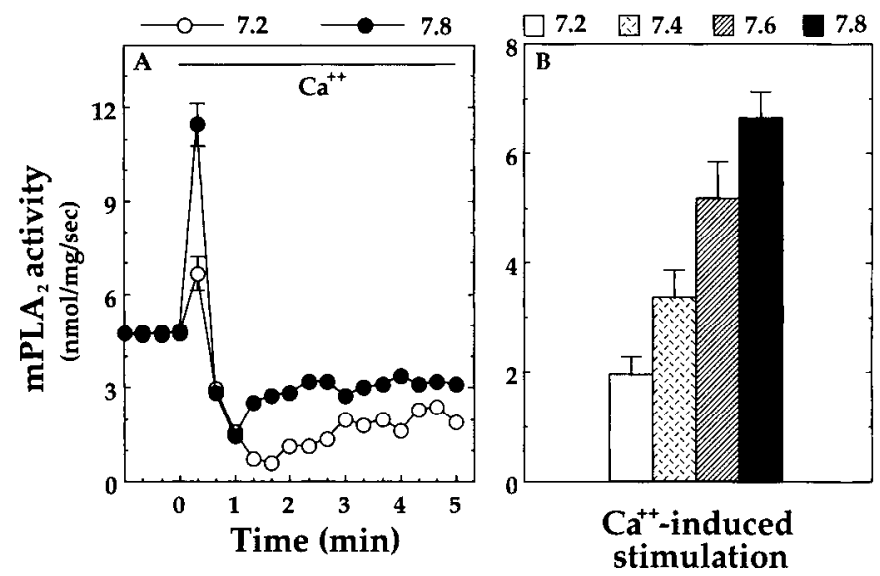

Figure 8. pH Sensitivity of membrane-bound $\mathrm{Ca}^{2+}$-dependent PLA, activity. $A$, Membranes were prepared from three independent neuronal cultures and InPLA $_{2}$ activity was measured in a $50 \mathrm{~mm}$ Tris- $\mathrm{HCl}$ medium buffered at indicated $\mathrm{pH}$, as described in Materials and Methods. Data are the result of $n=4$ independent measurements of mPLA activity expressed in nmol of pyrenedecanoate released/mg of protein/ sec. For graphic clarity, only $1 \mathrm{~min}$ of the basal, $\mathrm{Ca}^{2+}$-independent, mPLA $_{2}$ activity are represented, and error bars are indicated only the time point at $20 \mathrm{sec}$ after $\mathrm{Ca}^{2+}$ addition. At other time-point, SEM were $<10 \% . B$, The $\mathrm{Ca}^{2+}$-induced stimulation of mPLA $_{2}$ activity expressed as (nmol of pyrenedecanoate released over basal $/ \mathrm{mg}$ of protein $/ \mathrm{sec}$ ) measured between 5 and $20 \mathrm{sec}$ after application of $\mathrm{Ca}^{2+} \cdot \mathrm{mPLA}_{2}$ activity was measured as described in $A$. 

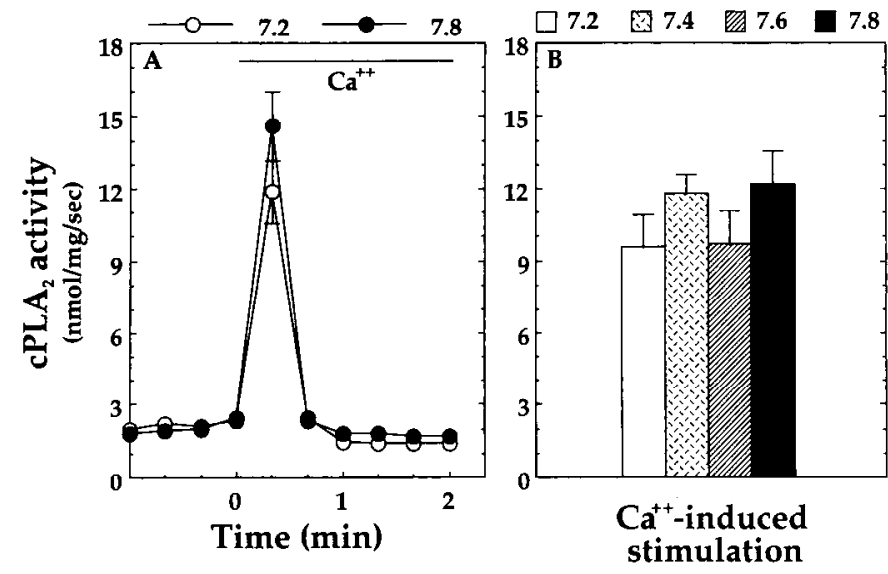

Figure 9. $\mathrm{pH}$ Insensitivity of cytoplasmic $\mathrm{PLA}_{2}$ activity. A, Cytoplasm were prepared from three independent neuronal cultures, and $\mathrm{CPL} \Lambda_{2}$ activity was measured in a $50 \mathrm{~mm}$ Tris- $\mathrm{HCl}$ medium buffered at indicated $\mathrm{pH}$ as described in Materials and Methods. Data are the result of $n=4$ independent measurements of cPLA, activily expressed in monol of pyrenedecanoate released $/ \mathrm{mg}$ of protein $/ \mathrm{sec}$. For graphic clarity, only 1 min of the basal, $\mathrm{Ca}^{2+}$-independent, $\mathrm{CPLA}_{2}$ activity are represented, and error bars are indicated only the time point at $20 \mathrm{sec}$ after $\mathrm{Ca}^{2+}$ addition. At other time point, SEM were $<10 \%, B$, The $\mathrm{Ca}^{2+}$-induced stimulation of cPLA, activity expressed as (nmol of pyrenedecanoate released over basal $/ \mathrm{mg}$ of protein/sec) measured between 5 and $20 \mathrm{sec}$ after application of $\mathrm{Ca}^{2+}$. CPLA $_{2}$ activity was measured as described in $A$.

rogenic $\mathrm{PLA}_{2}$ substrate, a basal $\mathrm{Ca}^{2+}$-independent cPLA $\mathrm{A}_{2}$ activity was measured $(2.3 \mathrm{nmol} / \mathrm{mg}$ of protein $/ \mathrm{sec})$. Increasing the $\mathrm{pH}$ of incubation medium from 7.2 to 7.8 did not change this basal $\mathrm{Ca}^{2+}$-independent $\mathrm{cPLA} \mathrm{A}_{2}$ activity, which was measured over a 2 min period (see Materials and Methods and Fig. 9A, before $\mathrm{Ca}^{2+}$ addition).

Addition of $2 \mathrm{mM} \mathrm{Ca}^{2+}$ revealed a $\mathrm{Ca}^{2+}$-dependent $\mathrm{CPLA}_{2}$ activity. $\mathrm{Ca}^{2+}$ induced a transient acceleration of the $\mathrm{CPLA}_{2} \mathrm{ac}-$ tivity with a maximum at $20 \mathrm{sec}$, which then returned to the initial basal activity after another $20 \mathrm{sec}$ (Fig. 9A). In contrast to $\mathrm{mPLA}_{2}$, this activity remained stable (Fig. $9 A$ ). As $\mathrm{pH}$ of the incubation medium was increased from 7.2 to 7.8 , the $\mathrm{Ca}^{2+}$ dependent $\mathrm{CPLA}_{2}$ measured at $20 \mathrm{sec}$ was not significantly affected (Fig. 9B).

\section{Discussion}

\section{Characterization of cortical neurons in primary culture}

In general, neurons in primary cultures are grown in a medium containing varying degrees of fetal serum; alternatively, the culture dishes are coated with serum. These procedures are known to enhance cell viability, but they also result in the presence of a certain percentage of either glial cells or at least glial precursors (DiPorzio et al., 1980). Since astrocytes influence neuronal functions and, in particular, glutamate responses (Bouvier et al., 1992; Glowinski et al., 1994; Parpura et al., 1994), it was important to examine the effect of glutamate on neuronal cultures grown in conditions that prevent glial proliferation. We therefore used cortical neurons cultured in the total absence of serum. Under these conditions, cortical neurons reached a maximal viability between 6 and 7 DIV (Fig. 1), similar to what has been described for mesencephalic neurons cultured under the same conditions (DiPorzio et al., 1980).

Virtually all cells were labeled by antibodies directed against neuronal markers (Fig. 2). In contrast, GFAP immunoreactivity was still absent at 11 DIV, a stage where astrocytes in culture have been shown to express this specific marker (Trimmer et al., 1982). These results strongly suggest that astrocytes were absent from the neuronal cultures used in this study.

It has been previously shown that cortical cultures exposed to glutamate results in a neurotoxicity, which is inversely related to the number of astrocytes present in the culture (Rosenberg et al., 1992); hence, neurotoxicity due to glutamate is higher in astrocyte-poor cultures. Furthermore, the toxicity of glutamate also depends on the age of neurons in primary culture; thus, neurons cocultured with astrocytes are sensitive to glutamate toxicity only after 13 DIV (Choi et al., 1987). Since, the culture conditions used in the present study yield cortical neurons in the absence of glial cells (see Materials and Methods) and reach their maximal viability at 6 DIV (Fig. 1), it was important to determine the potential neurotoxicity of glutamate under the experimental conditions used. As described in the Materials and Methods section, application of glutamate at $100 \mu \mathrm{M}$ for $15 \mathrm{~min}$ did not affect neuronal viability as indicated by Trypan blue exclusion.

\section{Excitatory amino acids induce the release of ${ }^{3} \mathrm{H}$-arachidonic acid from cortical neurons in primary culture}

We showed that glutamate stimulates the release of AA in mouse cerebral cortical neurons in glia-free primary cultures. It has been recognized that the physiological actions of glutamate are mediated by a family of receptors classified in three main classes: NMDA, AMPA/kainate, and metabotropic receptors (for review, see Nakanishi, 1992). Recent molecular and pharmacological studies have shown that several receptor subtypes exist for each of these classes.

The receptors mediating the glutamate-evoked release of AA in the present study are of the NMDA and AMPA classes. First, NMDA reproduces $56 \%$ of the glutamate response and the glutamate-evoked release of AA is reduced by half, both by competitive and noncompetitive antagonists of the NMDA receptors (Fig. 4; Results). Furthermore, aspartate, homocysteate, and cysteate also evoked approximately $50 \%$ of the glutamate maximal response. These excitatory amino acids are known to preferenlially aclivate NMDA receptors (Watkins et al., 1990), further confirming the involvement of NMDA receptors in part of the glutamate-evoked release of AA. Interestingly, a physiological role as endogenous excitatory neurotransmitters has been documented for aspartate, homocysteate, and cysteate (Watkins et al., 1990; Do et al., 1992). In line with results reported here, aspartate has also been shown to stimulate AA release in cerebellar granule cells with an efficacy that is $50 \%$ of that of glutamate (Lazarewicz et al., 1988).

Second, when $\Lambda \mathrm{MP} \Lambda$ receptor desensitization is prevented by concanavalin A, AMPA reproduces $53 \%$ of the glutamate response. Similarly, kainate exerts a stimulatory effect that reaches $36 \%$ of that observed with glutamate. The modest response induced by kainate could be due to its action on AMPA receptors, which are known to desensitize marginally after activation with this agonist (Barnard and Henley, 1990). The direct involvement of kainate receptors is unlikely, since the specific agonist of kainate receptors, that is, domoic acid (Watkins et al., 1990) was ineffective. Finally, the glutamate-evoked release of AA was reduced by approximately $50 \%$ by competitive antagonists of the AMPA/kainate receptors (Fig. 4; Results).

Third, metabotropic receptors do not appear to be involved in the glutamate-evoked release of AA, since neither an agonist 
mimicked nor an antagonist inhibited the effect of glutamate. Contrary to what has been described in 14 DIV striatal neurons in which the combined stimulation of AMPA and metabotropic receptors induces the release of AA (Dumuis et al., 1990, 1993), in $6 \mathrm{DIV}$ cortical neurons, metabotropic receptor activation has no effect on the AMPA response.

Finally, an additive stimulation of AA release occurs when NMDA and AMPA receptors are coactivated, which then totally reproduces the glutamate response. It is generally accepted that non-NMDA receptors are involved in low frequency cxcitatory amino acid-mediated synaptic transmission, whereas NMDA receptors become functionally operational mainly after further depolarization of the membrane (Herron et al., 1986) by removing the $\mathrm{Mg}^{2+}$ block of the channel (Mayer et al., 1984; Nowak et al., 1984). In view of its pharmacological profile, it is clear that activation of both receptor types is needed to achieve the full expression of the glutanate-evoked AA release.

\section{pH Sensitivity of the glutamate-evoked release of ${ }^{3} \mathrm{H}$-arachidonic acid}

A dependence on extracellular $\mathrm{pH}\left(\mathrm{pH}_{6}\right)$ has been previously reported for NMDA currents, while AMPA/kainate currents remained unaffected (Tang et al., 1990; Traynelis and Cull-Candy, 1990). In contrast, results reported here show that in addition to the NMDA-evoked release of AA, the effect of kainate is also enhanced in alkaline buffer (Fig. 7). These observations suggest that $\mathrm{pH}_{0}$ might not modify the glutamate-evoked release of AA by directly affecting the conductance of a given receptor-channel class, but rather by modulating an intracellular step further downstream in the pathway that leads to AA liberation.

It is well known that a crucial step involved in the glutamateevoked release of $\mathrm{AA}$ is the $\mathrm{Ca}^{2+}$ influx induced by glutamatergic receptor activation (Dumuis et al., 1988, 1993; Lazarewicz et al., 1990). If both NMDA- and kainate-induced $\left[\mathrm{Ca}^{2+}\right]_{i}$ increase were $\mathrm{pH}$ sensitive, this could be a possible mechanism responsible for the $\mathrm{pH}$ sensitivity of $\mathrm{AA}$ release induced by both agonists. However, this hypothesis can be ruled out, since both NMDA- and kainate-induced increases in $\left[\mathrm{Ca}^{2+}\right]_{i}$ were not significantly affected by $\mathrm{pH}_{o}$ (Table 1 ; Results). These observations are in agreement with a recent report indicating the $\mathrm{pH}$ insensitivity of the NMDA-induced $\mathrm{Ca}^{2+}$ influx in rat hippocampal neurons (Irwin et al., 1994).

$\mathrm{PLA}_{2}$ activity has been shown to be directly dependent on $\mathrm{H}^{+}$ concentration (Moskowitz et al., 1983). Indeed, we observed that $\mathrm{pH}_{\text {, }}$ rapidly increases the glutamate-evoked release of AA, since a significant difference was observed within $2 \mathrm{~min}$ glutamate application in a medium buffered at 7.8 versus 7.2 . These results are in agreement with the rapid switch in $\mathrm{pH}_{i}$ that occurs within scconds after changes in $\mathrm{pH}_{0}$ (Ou-yang et al., 1993). Furthermore, we demonstrated that manipulations known to directly affect $\mathrm{pH}_{i}$ also modified the glutamate-induced release of AA. Thus, it is well documented that when $\mathrm{NH}_{4} \mathrm{Cl}$ (in the $20-40 \mathrm{mM}$ range) is applied to the incubation medium, a biphasic variation in $\mathrm{pH}_{i}$ occurs (Raley-Susman et al., 1991): initially, neuronal $\mathrm{pH}_{i}$ increases (presumably due to the influx of the membrane-permeable base $\mathrm{NH}_{3}$; Schwiening and Boron, 1994), then an acidification rebound occurs when $\mathrm{NH}_{4} \mathrm{Cl}$ is removed (due to the activation of $\mathrm{pH}$ regulatory countertransport mechanisms). As shown in Table 2, when neuronal cultures are exposed to $\mathrm{NH}_{4} \mathrm{Cl}$, the glutamate-evoked release of ${ }^{3} \mathrm{H}-\mathrm{AA}$ is enhanced at a time point when the $\mathrm{pH}_{i}$ is alkaline.

Inhibition of both $\mathrm{Na}^{+} / \mathrm{H}^{+}$and the $\mathrm{Cl}^{-} / \mathrm{HCO}_{3}{ }^{-}$exchange have been shown to induce a $\mathrm{pH}_{i}$ acidification (L'Allemain et al., 1985; Raley-Susman et al., 1991). Indeed, when cortical neurons are treated with both harmaline or amiloride, two inhibitors of the $\mathrm{Na}^{+} / \mathrm{H}^{+}$exchange, the glutamate-evoked release of $\mathrm{AA}$ is strongly inhibited (Table 2). Interestingly, $\mathrm{Na}^{+} / \mathrm{H}^{+}$exchange in hippocampal neurons is sensitive to $100 \mu \mathrm{M}$ harmaline and insensitive to $1 \mathrm{~mm}$ amioride (Raley-Susman et al., 1991); whereas $\mathrm{Cl}^{-} / \mathrm{HCO}_{3}{ }^{-}$exchange is inhibited by $100 \mu \mathrm{M}$ DIDS (Schwiening and Boron, 1994). As shown in Table 2, DIDS also inhibited the glutamate-cvoked release of AA in cortical neurons.

Taken together, this set of results demonstrates that $\mathrm{pH}_{o}$ regulates the glutamate-evoked release of ${ }^{3} \mathrm{H}$-AA from cortical neurons, without significantly affecting the glutamate-evoked increase in $\left[\mathrm{Ca}^{2+}\right]_{i}$, but rather by directly affecting $\mathrm{pH}_{i}$.

\section{pH Sensitivity of $\mathrm{Ca}^{2+}$-dependent membrane-bound $P L A_{2}$ activity}

Data reported in this article clearly indicate that cortical neurons in primary cultures possess four different PLA $\mathrm{A}_{2}$ activities, that is, $\mathrm{Ca}^{2+}$-independent or $\mathrm{Ca}^{2+}$-dependent membrane-bound PLA $\mathrm{A}_{2}$ $\left(\mathrm{mPLA}_{2}\right)$ and cytoplasmic PLA $\mathrm{A}_{2}$ (cPLA $)_{2}$ ) activities. These results are in agreement with those previously obtained in rat cortical synaptosomes (Piomelli and Greengard, 1991). Various molecular mechanisms underlying the $\mathrm{Ca}^{2+}$-dependent activation of either $\mathrm{cPLA}_{2}$ or $\mathrm{mPLA}_{2}$ activity could be considered. For example, $\mathrm{Ca}^{2+}$ activated proteins, such as protein kinase $\mathrm{C}(\mathrm{Lin}$ et al., 1992) and $\mathrm{Ca}^{2+} / \mathrm{calmodulin}$ kinase II (Piomelli and Greengard, 1991) have been shown to regulate PLA $\mathrm{P}_{2}$ activity. Alternatively, $\mathrm{Ca}^{2+}$ may directly activate $\mathrm{PLA}_{2}$, since this ion has been shown to directly bind CPLA $_{2}$ (Clark et al., 1991).

In the present study, we studied the $\mathrm{pH}$ sensitivity of the four different PLA $\mathrm{A}_{2}$ activities. We observed that only the $\mathrm{Ca}^{2+}$-dependent $\mathrm{mPLA}_{2}$ activity is modulated by $\mathrm{pH}$ (Fig. $8 A, B$ ), while the $\mathrm{Ca}^{2+}$-independent $\mathrm{mPLA}_{2}$ activity is not. Furthermore, both $\mathrm{Ca}^{2+}$-independent and $\mathrm{Ca}^{2+}$-dependent $\mathrm{CPI} \cdot \mathrm{A}_{2}$ activities are $\mathrm{pH}$ insensitive (Fig. 9A,B). Thus, considering the fact that $\mathrm{pH}_{i}$ alkalinization enhances $\mathrm{mPLA}_{2}$ activity, it can be postulated that as $\mathrm{pH}_{i}$ changes to alkaline values, a $\mathrm{Ca}^{2+}$ influx due to glutamatergic receptor activation will then preferentially stimulate $\mathrm{mPLA}_{2}$ activity. Indeed, the glutamate-evoked release of AA requires $\mathrm{Ca}^{2+}$ influx (Dumuis et al., 1988, 1993; Lazarewicz et al., 1990) ruling out the $\mathrm{Ca}^{2+}$-independent PLA $\mathrm{A}_{2}$ activities. In addition, stimulation of AA release by activation of NMDA and AMPA receptors are $\mathrm{pH}$ sensitive (Fig. 7), with a $\mathrm{pH}$ profile similar to that $\mathrm{pH}$ profile of $\mathrm{Ca}^{2+}$-dependent $\mathrm{mPLA}_{2}$ activity. It should be emphasized that, in the experimental condition used in this study, that is, measuring PLA $\mathrm{A}_{2}$ activity with PPC, it is not possible to asses the translocation of $\mathrm{CPLA}_{2}$, since cytoplasm and plasma membranes were analyzcd separately. Neverthelcss, it cannot be exclude that $\mathrm{CPLA}_{2}$ or related enzyme could also be involved once it has translocated to the membrane of intact neurons.

The exact molecular mechanism(s) involved in the $\mathrm{pH}$ sensitivity of $\mathrm{mPLA}_{2}$ activity remain(s) to be clarified. Reports on human U937 cells cPLA 2 have shown that this $85.2 \mathrm{kd}$ protein contains a $\mathrm{Ca}^{2}$-dependent domain (Clark et al., 1991). Whether $\mathrm{H}^{+}$concentration directly influences this domain or whether $\mathrm{pH}$ alters the properties of cofactors necessary for PLA $\mathrm{P}_{2}$ activity is not known. In keeping with previous observations in rat cortical synaptosomes (Piomelli and Greengard, 1991), the $\mathrm{Ca}^{2+}$-dependent activity of the $\mathrm{mPLA}_{2}$ was modulated in a biphasic manner by $\mathrm{Ca}^{2+}$. Thus, after a rapid $(20 \mathrm{sec})$ increase in activity follow- 
ing $\mathrm{Ca}^{2+}$ addition, $\mathrm{mPLA}_{2}$ activity decreased rapidly and was actually inhibited to levels lower than basal (Fig. $8 A$ ). This inhibition has been interpreted as a negative feed-back mechanism exerted by $\mathrm{Ca}^{2+}$ acting through a $\mathrm{Ca}^{2+} /$ calmodulin kinase II (Piomelli and Greengard, 1991). As shown in Figure 8, alkalinization enhances the initial $\mathrm{Ca}^{2+}$-dependent activation of mPLA $_{2}$ (Fig. 8B) and decreases the $\mathrm{Ca}^{2+}$-mediated feed-back inhibition (Fig. 8A); thus, the net result of alkalinization is a long-lasting increase in $\mathrm{MPLA}_{2}$ activity.

Following electrically induced depolarization, a $1-2 \min \mathrm{pH}_{o}$ alkalinization is observed (Kraig et al., 1983; Chesler and Chan, 1988). It has been proposed that $\mathrm{pH}_{o}$ changes are due to the exchange of $\mathrm{H}^{+}$equivalents principally between the interstitial space and surrounding glial cells (Chesler, 1990; Ransom, 1992). In line with this hypothesis, Bouvier et al. demonstrated that glutamate uptake into glial cells is associated with the countertransport of $\mathrm{OH}^{-}$into the extraccllular medium (Bouvicr et al., 1992). Thus, the extracellular alkalinization could result from this neuronal-glial interaction due to glutamate reuptake into astrocytes. Changes in $\mathrm{pH}_{o}$ lasting for several minutes could modulate neuronal responses by affecting the properties of membrane proteins such as receptors that possess a domain facing the extracellular space. Indeed, NMDA currents determined in the whole-cell mode are $\mathrm{pH}_{\text {o }}$ sensitive (Tang et al., 1990; Traynelis and Cull-Candy, 1990). Accordingly, epileptiform activity mediated by NMDA receptors is enhanced by $\mathrm{pH}_{\theta}$ alkalinization and dampened by $\mathrm{pH}_{0}$ acidification (Aram and Lodge, 1987).

Intracellular $\mathrm{pH}$ is also altered during glutamate neurotransmission. First, changes in $\mathrm{pH}_{t}$ influence $\mathrm{pH}_{i}$ within seconds by shifting its values in the same direction (Ou-yang et al., 1993). Second, it should be emphasized that activation of NMDA receptors per se has been described to induce long-term changes in intracellular $\mathrm{H}^{+}$homeostasis. This mechanism provides an additional level of complexity to the modulation of intracellular $\mathrm{H}^{+}$concentration. Indeed, activation of NMDA receptors first induces a transient $\mathrm{pH}_{\text {, }}$ acidification (Endres et al., 1986; Irwin et al., 1994) followed by $\mathrm{pH}_{i}$ alkalinization that can persist for several hours (Hartley and Dubinsky, 1993). This long-lasting alkalinization will enhance the efficacy of glutamate in evoking AA release upon subsequent activation, thus providing a longlasting facilitation of specific signal transduction pathway at glutamatergic synapse.

Certain components of long-term potentiation (LTP) appear to involve AA formation (Williams et al., 1989; Drapeau et al., 1990). AA can, in fact, regulate the efficacy of glutamatergic neurotransmission by increasing NMDA currents (Miller et al., 1992) or glutamate concentration in the synaptic cleft (Yu et al., 1986; Barbour et al., 1989; Herrero et al., 1992; Volterra et al., 1992). Since glutamate evokes long-lasting $\mathrm{pH}_{i}$ alkalinizations (Hartley and Dubinsky, 1993), which, in turn, enhances the capacity of glutamate to evoke AA release, it may be suggested from the foregoing that the $\mathrm{pH}$ sensitivity of glutamate-evoked AA release may contribute to the long-lasting increase in synaptic efficacy characterized for LTP.

\section{References}

Aram JA, Lodge D (1987) Epileptiform activity induced by alkalosis in rat neocortical slices: block by antagonists of $N$-methyl-D-aspartate. Neurosci Lett 83:345-350.

Barbour B, Szatkowski M, Ingledew N, Attwell D (1989) Aracnidonic acid induces a prolonged inhibition of glutamate uptake into glial cells. Nature 342:918-920.

Barnard EA, Henley JM (1990) The non-NMDA receptors: types, pro- tein structure and molecular biology. Trends Pharmacol Sci 11:500507.

Berridge MJ, Downes CP, Hanley MR (1982) Lithium amplifies agonist-dependent phosphatidylinositol responses in brain and salivary glands. Biochem J 206:587-595.

Bouvier M, Szatkowski M, Amato A, Attwell D (1992) The glial cell glutamate uptake carrier countertransports pH-changing anions. Nature $360: 471-474$.

Bradford MM (1976) A rapid and sensitive method for the quantitation of microgram quantities of protein utilizing the principle of proteindye binding. Ann Biochem 72:248-254.

Chesler M (1990) The regulation and modulation of $\mathrm{pH}$ in the nervous system. Prog Neurobiol 34:401-427.

Chesler M, Chan CY (1988) Stimulus-induced extracellular pH transients in the in vitro turtle cerebellum. Neuroscience 27:911-948.

Choi DW, Maulucci-Gedde M, Kriegstein AR (1987) Glutamate neurotoxicity in cortical cell culture. J Neurosci 7:357-368.

Clark JD, Lin LL, Kriz RW, Ramesha CS, Sultzman LA, Lin AY, Milona N, Knopf JL (1991) A novel arachidonic acid-selective cytosolic $\mathrm{PLA}_{2}$ contains a $\mathrm{Ca}^{2+}$-dependent translocation domain with homology to PKC and GAP. Cell 65:1043-1051.

Dahl D (1988) Early and late appearance of neurofilament phosphorylated epitopes in rat nervous system development: in vivo and in vitro study with monoclonal antibodies. J Neurosci Res 20:431-441.

Denizot F, Lang R (1986) Rapid colorimetric assay for cell growth and survival. J Immunol Methods 89:271-277.

Dennis EA (1994) Diversity of group types, regulation, and function of phospholipase $A_{2}$. J Biol Chem 269:13057-13060.

DiPorzio U, Daguet M-C, Glowinski J, Prochiantz A (1980) Effect of striatal cells on in vitro maturation of mesencephalic dopaminergic neurones grown in serum-free conditions. Nature 288:370-373.

Do KQ, Grandes P, Hansel C, Jiang $Z$ P, Klancnik J, Streit P, Tschopp P, Zaengerle L, Cuenod M (1992) Sulphur containing excitatory amino acids: release, activity and localization. Mol Neuropharmacol $2: 39-42$

Drapeau C, Pellerin L, Wolfe LS, Avoli M (1990) Long-term changes of synaptic transmission induced by arachidonic acid in the CA1 subfield of the rat hippocampus. Neurosci Lett 115:286-292.

Dumuis A, Sebben M, Haynes L, Pin J-P, Bockaert J (1988) NMDA receptors activate the arachidonic acid cascade system in striatal neurons. Nature 336:68-70.

Dumuis A, Pin J-P, Oomagari K, Sebben M, Bockaert J (1990) Arachidonic acid released from striatal neurons by joint stimulation of ionotropic and metabotropic quisqualate receptors. Nature 347:182184.

Dumuis A, Sebben M, Fagni L, Prézeau L, Manzoni O, Cragoe EJ, Bockaert J (1993) Stimulation by glutamate receptors of arachidonic acid release depends on the $\mathrm{Na}^{+} / \mathrm{Ca}^{2+}$ exchanger in neuronal cells. Mol Pharmacol 43:976-981.

El-Etr M, Cordier J, Glowinski J, Prémont J (1989) A neuroglial cooperativity is required for the potentiation by 2 -chloroadenosine of the muscarinic-sensitive phospholipase $\mathrm{C}$ in the striatum. J Neurosci 9:1473-1480.

El-Etr M, Marin P, Tencé M, Delumeau J-C, Cordier J, Glowinski J, Prémont J (1992) 2-Chloroadenosine potentiates the $\alpha 1$-adrenergic activation of phospholipase $\mathrm{C}$ through a mechanism involving arachidonic acid and glutamate in striatal astrocytes. J Neurosci 12: $1363-1369$

Endres W, Ballanyi K, Serve G, Grafe P (1986) Excitatory amino acids and intracellular $\mathrm{pH}$ in motoneurons of the isolated frog spinal cord. Neurosci Lett 72:54-58.

Frei K, Siepl C, Groscurth P, Bodmer S, Schwerdel C, Fontana A (1987) Antigen presentation and tumor cytotoxicity by interferon- $\gamma$ treated microglia cells. Eur J Immunol 17:1271-1278.

Glowinski J, Marin P, Tencé M, Stella N, Giaume C, Prémont J (1994) Glial receptors and their intervention in astrocyto-astrocytic and astrocyto-neuronal interactions. Glia 11:201-208.

Grynkiewicz G, Poenie M, Tsien RY (1985) A new generation of $\mathrm{Ca}^{2+}$ indicators with greatly improved fluorescence properties. J Biol Chem 260(6):3440-3450.

Hartley Z, Dubinsky JM (1993) Changes in intracellular pH associated with glutamate excitotoxicity. J Neurosci 13:4690-4699.

Herrero I, Miras-Portugal MT, Sanchez-Prieto J (1992) Positive feedback of glutamate exocytosis by metabotropic presynaptic receptor stimulation. Nature 360:163-166. 
Herron CF, I ester RAJ, Coan EJ, Collingridge GL (1986) Frequencydependent involvement of NMDA receptors in the hippocampus: a novel synaptic mechanism. Nature 322:265-268.

Huettner JE (1990) Glutamate receptor channels in rat dorsal root ganglion neurons: activation by kainate and quisqualate, blockade of desensitization by concanavalin A. Neuron 5:255-266.

Hurst JS, Flatman S, McDonald-Gibson RG (1987) Thin-layer chromatography (including radio thin-layer chromatography and autoradiography) of prostaglandins and related compounds. In: Prostaglandins and related substances: practical approach (Benedetto $\mathrm{C}$ et al., eds), pp 53-73. Washington, DC: Oxford IRL.

Irvine RF (1982) How is the level of free arachidonic acid controlled in mammalian cells? Biochem J 204:3-16.

Irwin RP, Lin S-Z, Long RT, Paul SM (1994) N-Methyl-D-aspartate induces a rapid, reversiblc, and calcium-dependent intracellular acidosis in cultured fetal rat hippocampal neurons. J Neurosci 14:13521357

Johnson JW, Ascher P (1987) Glycine potentiates the NMDA response in cultured mouse brain neurons. Nature 325:529-531.

Kraig RP, Ferreira-Fitho CR, Nicholson C (1983) Alkaline and acid transients in cerebellar microenvironment. J Neurophysiol 49:831850.

L'Allemain $G_{2}$ Paris $S$, Pouysségur J (1985) Role of a $\mathrm{Na}^{+}$-dependent $\mathrm{Cl}^{-} / \mathrm{HCO}_{3}$ exchange in regulation of intracellular $\mathrm{pH}$ in fibroblasts. J Biol Chem 260:4877-4883.

Lazarewicz JW, Wroblewski JT, Palmer ME, Costa E (1988) Activation of $N$-methyl-D-aspartate-sensitive glutamate receptors stimulates arachidonic acid releases in primary cultures of cerebellar granule cells. Neuropharmacology 27:765-769

Lazarewicz JW, Wroblewski JT, Costa E (1990) $\mathrm{N}$-methyl-D-aspartatesensitive glutamate receptors induce calcium-mediated arachidonic acid release in primary cultures of cerebellar granule cells. J Neurochem 55:1875-1881.

Lin LL, Lin AY, Knopf JL (1992) Cytosolic phospholipase A, is coupled to hormonally regulated release of arachidonic acid. Proc Natl Acad Sci USA 89:6147-6151.

Marin P, Stella N, Cordier J, Glowinski J, Prémont J (1993) Role of arachidonic acid and glutamate in the formation of inositol phosphates induced by noradrenalin in striatal astrocytes. Mol Pharmacol 44: 1176-1184.

Mayer ML, Westbrook GL, Guthrie PB (1984) Voltage-dependent block by $\mathrm{Mg}^{2+}$ of NMDA responses in spinal cord neurones. Nature 309:261-263

Miller B, Sarantis M, Traynelis SF, Attwell D (1992) Potentiation of NMDA receptor currents by arachidonic acid. Nature 355:722-725.

Moskowitz N, Puszkin S, Schook W (1983) Characterization of brain synaptic vesicle phospholipase $\mathrm{A}_{2}$ activity and its modulation by calmodulin, prostaglandin $\mathrm{E}_{2}$, proslaglandin $\mathrm{F}_{2 \alpha}$, cyclic AMP, and ATP. J Neurochem 41:1576-1586.

Nakanishi S (1992) Molecular diversity of glutamate receptors and implication for brain function. Science 258:597-603

Nowak L, Bregestovski P, Ascher P, Herbet A, Prochiantz A (1984) Magnesium gates glutamate-activated channels in mouse central neurones. Nature 307:462-465.

Oomagari K, Buisson B, Dumuis A, Bockaert J, Pin JP (1991) Effect of glutamate and ionomycin on the release of arachidonic acid, pros taglandins and HETEs from cultured neurons and astrocytes. Eur J Neurosci 3:928-939.

Ou-yang Y, Mellergard P, Siesjö B (1993) Regulation of intracellular $\mathrm{pH}$ in single rat cortical neurons in vitro: a microspectrofluorometric study. J Cereb Blood Flow Metab 13:827-840.

Parpura V, Basarsky TA, Liu F, Jeftinija K, Jeftinija S, Haydon PG (1994) Glutamate-mediated astrocyte-neuron signalling. Nature 369 : 744-747.

Patel AJ, Sanfeliu C, Hunt A (1990) Development and regulation of excitatory amino acid receptors involved in the release of arachidonic acid in cultured hippocampal neuronal cells. Dev Brain Res 57:5562

Pellerin L, Wolfe LS (1991) Release of arachidonic acid by NMDA- receptor activation in the rat hippocampus. Neurochem Res 16:983989.

Petrou S, Ordway RW, Singer JJ, Walsh JV (1993) A putative fatty acid-binding domain of the NMD $\Lambda$ receptor. Trends Pharmacol Sci 18:41-42.

Pin J-P, Joly C, Heinemann SF, Bockaert J (1994) Domains involved in the specificity of $\mathrm{G}$ protein activation in phospholipase C-coupled metabotropic glutamate receptors. EMBO J 13(2):342-348.

Piomelli D, Greengard P (1991) Bidirectional control of phospholipase $\mathrm{A}_{2}$ activity by $\mathrm{Ca}^{2+} /$ calmodulin-dependent protein kinase II, cAMP dependent protein kinase, and casein kinase II. Proc Natl Acad Sci USA (88):6770-6774.

Raley-Susman KM, Cragoe EJ, Sapolsky RM, Kopito RR (1991) Regulation of intracellular $\mathrm{pH}$ in cultured hippocampal neurons by an amiloride-insensitive $\mathrm{Na}^{+} / \mathrm{H}^{+}$exchanger. J Biol Chem 266(5):27392745.

Ransom BR (1992) Glial modulation of neural excitability by extracellular pH: a hypothesis. In: Progress in brain research (Yu ACH et al., eds), pp 37-46. New York: Elsevier.

Rosenberg PA, Amin SA, Leitner M (1992) Glutamate uptake disguises neurotoxic potency of glutamate agonists in cerebral cortex in dissociated cell culture. J Neurosci 12:56-61.

Sanfeliu C, Hunt A, Patel AJ (1990) Exposure to $N$-methyl-D-aspartate increases release of arachidonic acid in primary cultures of rat hippocampal neurons and not in astrocytes. Brain Res 526:241-248.

Schwiening CJ, Boron WF (1994) Regulation of intracellular $\mathrm{pH}$ in pyramidal neurones from the rat hippocampus by $\mathrm{Na}^{+}$-dependent $\mathrm{Cl}^{-}-\mathrm{HCO}_{3}{ }^{-}$exchange. J Physiol (Lond) 475:59-67.

Secchi J, Lecaque D, Cousin M-A, Lando D, Legault-Demare L, Raynaud J-P (1980) Detection and localization of 14-3-2 protein in primary cultures of embryonic rat brain. Brain Res 184:455-466.

Slater TF, Sawyer B, Sträuli U (1963) Studies on succinate-tetrazolium reductase systems. BBA 77:383-393.

Stella N, Tencé M, Glowinski J, Prémont J (1994) Glutamate-evoked release of arachidonic acid from mouse brain astrocytes. J Neurosc $14: 568-575$.

Stryer L (1988) Protein conformation, dynamics, and function. In: Biochemistry. pp 154-156. New York: Freeman

Tabb JS, Kish PE, Van Dyke R, Ueda T (1992) Glutamate transport into synaptic vesicles: roles of membrane potential, $\mathrm{pH}$ gradient, and intravesicular $\mathrm{pH}$. JBC 267:15412-15418.

Tang C-M, Dichter M, Morad M (1990) Modulation of the N-methylD-aspartate channels by extracellular $\mathrm{H}^{+}$. Proc Natl Acad Sci USA 87:6115 6149

Tapia-Arancibia L, Rage F, Astier H (1990) Activation of N-methyl-Daspartate receptors induces arachidonic acid release and somatostatin secretion in cortical and hypothalamic neurons. Neurochem Int 16[Suppl 1]:70.

Tapia-Arancibia L, Rage F, Récasens M, Pin JP (1992) NMDA receptor activation stimulates phospholipase $\mathrm{A} 2$ and somatostatin release from rat cortical neurons in primary cultures. Eur J Pharmacol 225(3):253262

Traynelis SF, Cull-Candy SG (1990) Proton inhibition of $N$-methyl-Maspartate receptors in cerebellar neurons. Nature 345:347-350.

Trimmer P, Reier P, Oh T, Eng L (1982) An ultrastructural and immunocytochemical study of astrocytic differentiation in vitro. J Neuroimmunol 2:235-260.

Volterra A, Trotti D, Cassutti P, Tromba C, Salvaggio A, Melcangi RC, Racagni $G$ (1992) High sensitivity of glutamate uptake to extracellular free arachidonic acid levels in rat cortical synaptosomes and astrocytes. J Neurochem 59:600-606

Watkins JC, Krogsgaard-Larsen P, Honoré T (1990) Structure-activity relationship in the development of excitatory amino acid receptor agonists and competitive antagonists. Trends Pharmacol Sci 11:2533.

Williams JH, Errington ML, Lynch MA, Bliss TVP (1989) Arachidonic acid induces a long-term activity-dependent enhancement of synaptic transmission in the hippocampus. Nature 341:739 742 .

Yu ACH, Chan PH, Fishman RA (1986) Effects of arachidonic acid on glutamate and $\gamma$-anninubutyric acid uplake in primary cultures of rat cerebral cortical astrocytes and neurons. J Neurochem 47:11811189 . 